\title{
Baseline Survey Instruments: Adolescent Girls Initiative-Kenya
}

Population Council

Follow this and additional works at: https://knowledgecommons.popcouncil.org/departments_sbsr-pgy

Part of the Demography, Population, and Ecology Commons, Family, Life Course, and Society Commons, Health Communication Commons, and the International Public Health Commons How does access to this work benefit you? Let us know!

\section{Recommended Citation}

"Baseline Survey Instruments: Adolescent Girls Initiative-Kenya." Nairobi: Population Council, 2015. 


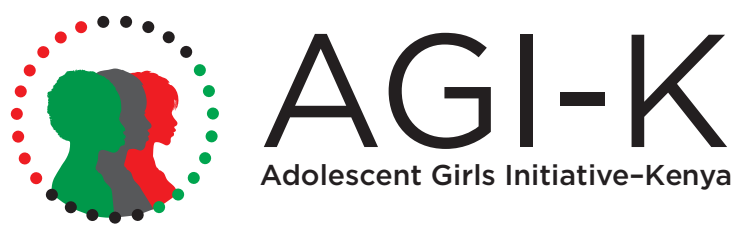

\section{Baseline Survey Instruments}




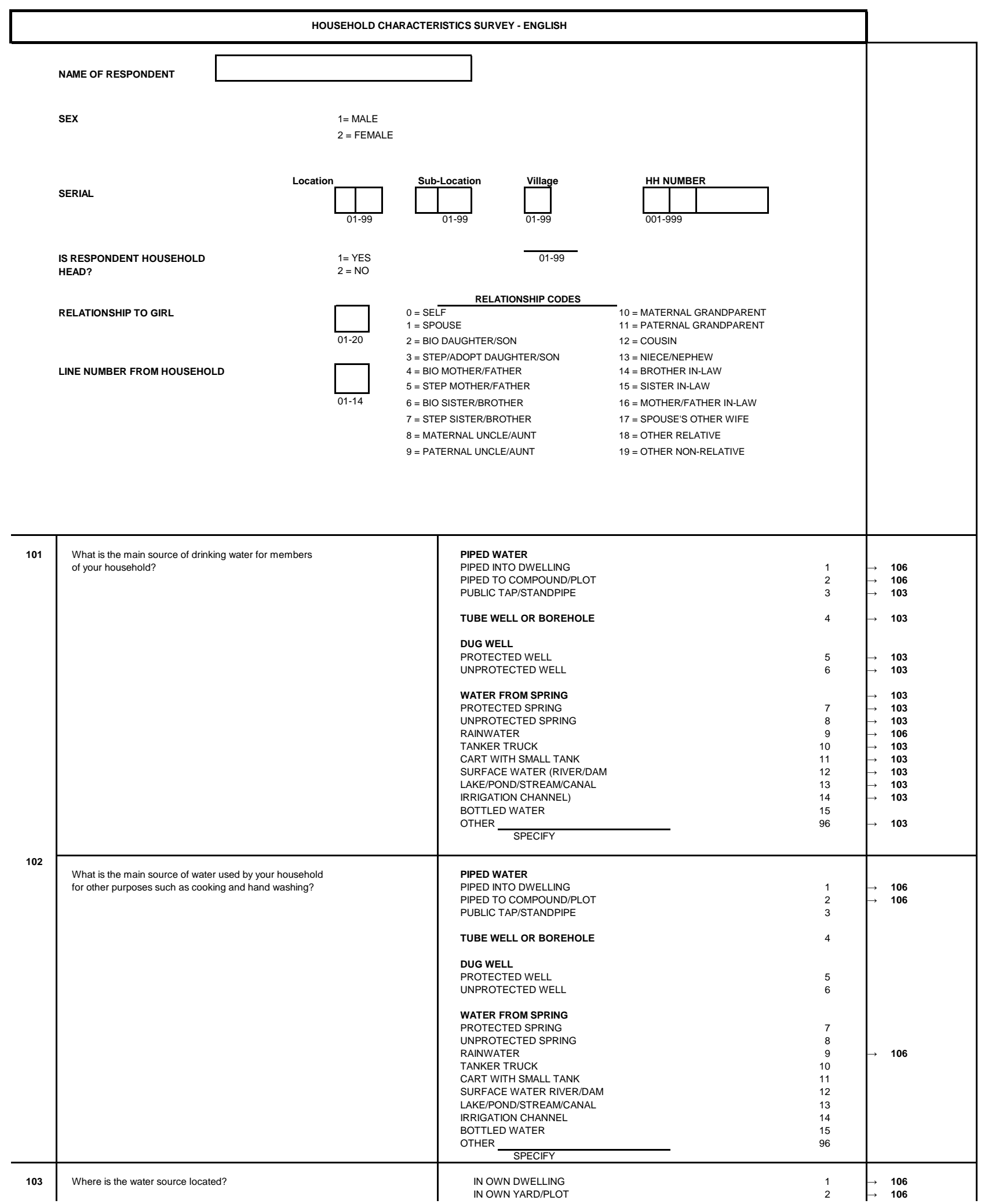




\begin{tabular}{|c|c|c|c|c|}
\hline & & ELSEWHERE & 3 & \\
\hline 104 & How long does it take to go there, get water and come back? & $\begin{array}{ll}\text { a. } & \text { HOURS } \\
& {[0-5]} \\
\text { b. } & \text { MINUTES } \\
& {[0-59]}\end{array}$ & & \\
\hline & & DON'T KNOW & 88 & \\
\hline 105 & $\begin{array}{l}\text { Who usually goes to this source to fetch water for your } \\
\text { house hold? }\end{array}$ & $\begin{array}{l}\text { ADULT WOMAN } \\
\text { ADULT MAN } \\
\text { FEMALE CHILD UNDER } 15 \text { YEARS OLD } \\
\text { MALE CHILD UNDER } 15 \text { YEARS OLD } \\
\text { OTHER } \quad \frac{}{\text { SPECIFY }}\end{array}$ & $\begin{array}{r}1 \\
2 \\
3 \\
4 \\
96\end{array}$ & \\
\hline 106 & $\begin{array}{l}\text { What kind of toilet facility do members of your house hold } \\
\text { use? }\end{array}$ & $\begin{array}{l}\text { FLUSH OR POUR FLUSH TOILET } \\
\text { FLUSH TO PIPED SEWER SYSTEM } \\
\text { FLUSH TO SEPTIC TANK } \\
\text { FLUSH TO PIT LATRINE } \\
\text { FLUSH TO SOMEWHERE ELSE } \\
\text { FLUSH, DON'T KNOW WHERE } \\
\text { PIT LATRINE } \\
\text { VENTILATED IMPROVED PIT LATRINE } \\
\text { PIT LATRINE WITH SLAB } \\
\text { PIT LATRINE WITHOUT SLAB/ OPEN PIT } \\
\text { COMPOSTING TOILET } \\
\text { BUCKET TOILET } \\
\text { HANGING TOILET/HANGING LATRINE } \\
\text { NO FACILITY/BUSH/FIELD } \\
\text { OTHER } \quad \text { SPECIFY }\end{array}$ & $\begin{array}{r}1 \\
2 \\
3 \\
4 \\
5 \\
\\
\\
6 \\
7 \\
8 \\
9 \\
10 \\
11 \\
12 \\
96\end{array}$ & $\rightarrow \quad 109$ \\
\hline 107 & Do you share this toilet facility with other households? & 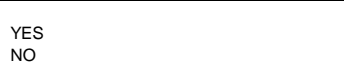 & $\begin{array}{l}1 \\
2\end{array}$ & $\rightarrow \quad 109$ \\
\hline 108 & How many households use this toilet facility? & $\begin{array}{l}\text { NO. OF HOUSEHOLDS } \\
\text { IF LESS THAN } 10 \\
10 \text { OR MORE HOUSEHOLDS } \\
\text { DON'T KNOW }\end{array}$ & \begin{tabular}{l|} 
\\
95 \\
98
\end{tabular} & \\
\hline 109 & $\begin{array}{l}\text { What type of fuel does your household mainly use } \\
\text { for cooking? }\end{array}$ & $\begin{array}{l}\text { ELECTRICITY } \\
\text { LPG/NATURAL GAS } \\
\text { BIOGAS } \\
\text { KEROSENE } \\
\text { CHARCOAL } \\
\text { WOOD } \\
\text { STRAW/SHRUBS/GRASS } \\
\text { AGRICULTURAL CROP } \\
\text { ANIMAL DUNG } \\
\text { NO FOOD COOKED IN HOUSEHOLD } \\
\text { OTHER } \\
\end{array}$ & $\begin{array}{r}1 \\
2 \\
3 \\
4 \\
5 \\
6 \\
7 \\
8 \\
9 \\
10 \\
96\end{array}$ & \\
\hline 110 & $\begin{array}{l}\text { MAIN MATERIAL OF THE FLOOR } \\
\text { [RECORD OBSERVATIONS] }\end{array}$ & 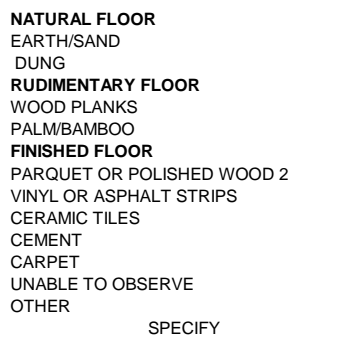 & $\begin{array}{r}1 \\
2 \\
4 \\
5 \\
\\
6 \\
7 \\
8 \\
9 \\
10 \\
77 \\
96\end{array}$ & \\
\hline 111 & $\begin{array}{l}\text { MAIN MATERIAL OF THE ROOF } \\
\text { [RECORD OBSERVATIONS.] }\end{array}$ & $\begin{array}{l}\text { NATURAL ROOFING } \\
\text { GRASS / THATCH / MAKUTI } \\
\text { DUNG / MUD } \\
\text { RUDIMENTARY ROOFING } \\
\text { CORRUGATED IRON (MABATI) } \\
\text { TIN CANS } \\
\text { FINISHED ROOFING } \\
\text { ASBESTOS SHEET } \\
\text { CONCRETE } \\
\text { TILES } \\
\text { UNABLE TO OBSERVE } \\
\text { OTHER } \frac{\text { SPECIFY }}{2}\end{array}$ & $\begin{array}{r}1 \\
2 \\
4 \\
5 \\
7 \\
8 \\
9 \\
77 \\
96\end{array}$ & \\
\hline 112 & $\begin{array}{l}\text { MAIN MATERIAL OF THE WALL } \\
\text { [RECORD OBSERVATIONS.] }\end{array}$ & $\begin{array}{l}\text { NATURAL WALLS } \\
\text { NO WALLS } \\
\text { CANE/PALM/TRUNKS } \\
\text { DIRT/MUD } \\
\text { RUDIMENTARY WALLS } \\
\text { BAMBOO WITH MUD }\end{array}$ & $\begin{array}{l}1 \\
2 \\
3 \\
4\end{array}$ & \\
\hline
\end{tabular}




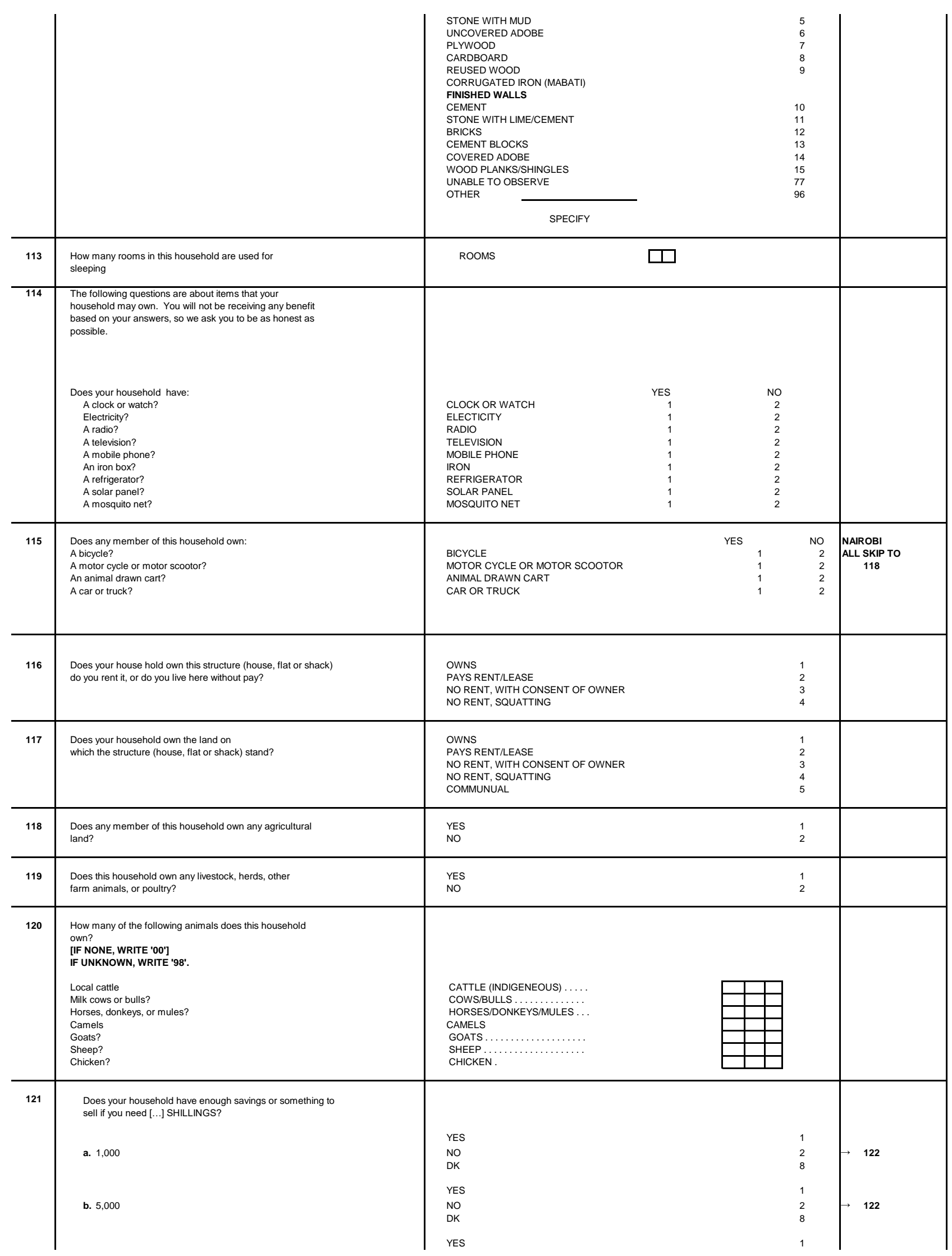




\begin{tabular}{|c|c|c|c|c|c|}
\hline & c. 10,000 & $\begin{array}{l}\text { NO } \\
\text { DK }\end{array}$ & & $\begin{array}{l}2 \\
8\end{array}$ & \\
\hline 122 & $\begin{array}{l}\text { How many children in this household attended primary school in the previous } \\
\text { school year? }\end{array}$ & NUMBER & NONE $\quad \square$ & & $\rightarrow \quad 125$ \\
\hline 123 & $\begin{array}{l}\text { How much did you pay for school fees/meals/parent association/maintenance } \\
\text { fees for children in primary school in the previous school year? }\end{array}$ & KSH & $\square \square$ & & \\
\hline 124 & $\begin{array}{l}\text { How much did you pay for uniforms/books/transport/other educational items } \\
\text { for children in primary school in the previous school year? }\end{array}$ & KSH & $\square \square$ & & \\
\hline 125 & $\begin{array}{l}\text { How many children in this household attended secondary school in the } \\
\text { previous school year? }\end{array}$ & NUMBER & $\square$ & & $\rightarrow \quad 201$ \\
\hline 126 & $\begin{array}{l}\text { How much did you pay for school fees/meals/parent association/maintenance } \\
\text { fees for children in secondary school in the previous school year? }\end{array}$ & KSH & \begin{tabular}{|l|l|l}
$\square$ &
\end{tabular} & & \\
\hline 127 & $\begin{array}{l}\text { How much did you pay for uniforms/books/transport/other educational items } \\
\text { for children in secondary school in the previous school year? }\end{array}$ & KSH & \begin{tabular}{l|l|l|} 
& & \\
\end{tabular} & & \\
\hline 201 & $\begin{array}{l}\text { HOUSE HOLD SH } \\
\text { In the last one year, has anyone died? [IF YES, ASK] How many? }\end{array}$ & Number of people & $\frac{\square}{N O N E}=00$ & & $\rightarrow \mathbf{2 0 3}$ \\
\hline 202 & How old was the person(s) when he/she died? & $\begin{array}{l}\text { PERSON } 1 \text { - AGE } \\
\text { PERSON } 2 \text { - AGE } \\
\text { PERSON } 3 \text { - AGE } \\
\text { PERSON } 4 \text { - AGE }\end{array}$ & +1 & & \\
\hline 203 & $\begin{array}{l}\text { In the last one year, was the household home lost due to fire, flood or } \\
\text { demolition, or other? }\end{array}$ & $\begin{array}{l}\text { NO } \\
\text { FIRE } \\
\text { FLOOD } \\
\text { DEMOLITION } \\
\text { OTHER }\end{array}$ & (SPECIFY) & $\begin{array}{r}0 \\
1 \\
2 \\
3 \\
96\end{array}$ & \\
\hline 204 & $\begin{array}{l}\text { In the last one year, did anyone in the household experience a major } \\
\text { illness? }\end{array}$ & $\begin{array}{l}\text { YES } \\
\text { NO }\end{array}$ & & $\begin{array}{l}1 \\
2\end{array}$ & \\
\hline 205 & $\begin{array}{l}\text { In the last one year, did any of the household breadwinners lose } \\
\text { their job? }\end{array}$ & $\begin{array}{l}\text { YES } \\
\text { NO }\end{array}$ & & $\begin{array}{l}1 \\
2\end{array}$ & \\
\hline \multirow[t]{2}{*}{206} & $\begin{array}{l}\text { In the last one month, was there a day that the household } \\
\text { went without food because there wasn't enough food in } \\
\text { the house hold? }\end{array}$ & $\begin{array}{l}\text { YES } \\
\text { NO }\end{array}$ & & $\begin{array}{l}1 \\
2\end{array}$ & \\
\hline & \multicolumn{5}{|c|}{ GENDER NORMS } \\
\hline 301 & Has [NAME] ever been married? & $\begin{array}{l}\text { YES } \\
\text { NO }\end{array}$ & & $\begin{array}{l}1 \\
2\end{array}$ & $\rightarrow \quad 303 \mid$ \\
\hline 302 & At what age do you expect [NAME] to get married? & 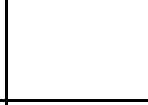 & $\begin{array}{l}\text { AGE } \\
\text { [10-50] } \\
\text { DON'T KNOW } \\
\text { DON'T EXPECT TO GET MARRIED }\end{array}$ & 1 & \\
\hline 303 & What is the highest level of school that you expect [NAME] to complete? & & $\begin{array}{l}\text { PRIMARY } \\
\text { SECONDARY } \\
\text { TECHNICAL/NOCATIONAL TRAINING (Post- Secondary) } \\
\text { UNIVERSITY } \\
\text { POST-GRADUATE } \\
\text { OTHER (SPECIFY) }\end{array}$ & $\begin{array}{r}1 \\
2 \\
3 \\
4 \\
4 \\
5 \\
96\end{array}$ & \\
\hline & $\begin{array}{l}\text { I am going to read you a few more statements and ask if you agree or di } \\
\text { INSERT THE NAME OF THE SELECTED DAUGHTER OF THE RESPONDENT. IF DAL }\end{array}$ & $\begin{array}{l}\text { ith them. } \\
\text { IAS/IS MARRIED, ASK }\end{array}$ & ABOUT THE TIME BEFORE SELECTED DAUGHTER GOT MARRIED. & & \\
\hline 304 & $\begin{array}{l}\text { When a family is poor and cannot send all children to school, } \\
\text { boys should be sent before girls. }\end{array}$ & & $\begin{array}{l}\text { AGREE } \\
\text { DISAGREE }\end{array}$ & $\begin{array}{l}1 \\
2\end{array}$ & \\
\hline 305 & $\begin{array}{l}\text { If a rich man offers to marry a } 16 \text {-year old girl, she should leave } \\
\text { school to get married. }\end{array}$ & & $\begin{array}{l}\text { AGREE } \\
\text { DISAGREE }\end{array}$ & $\begin{array}{l}1 \\
2\end{array}$ & \\
\hline 306 & & & AGREE & 1 & \\
\hline
\end{tabular}




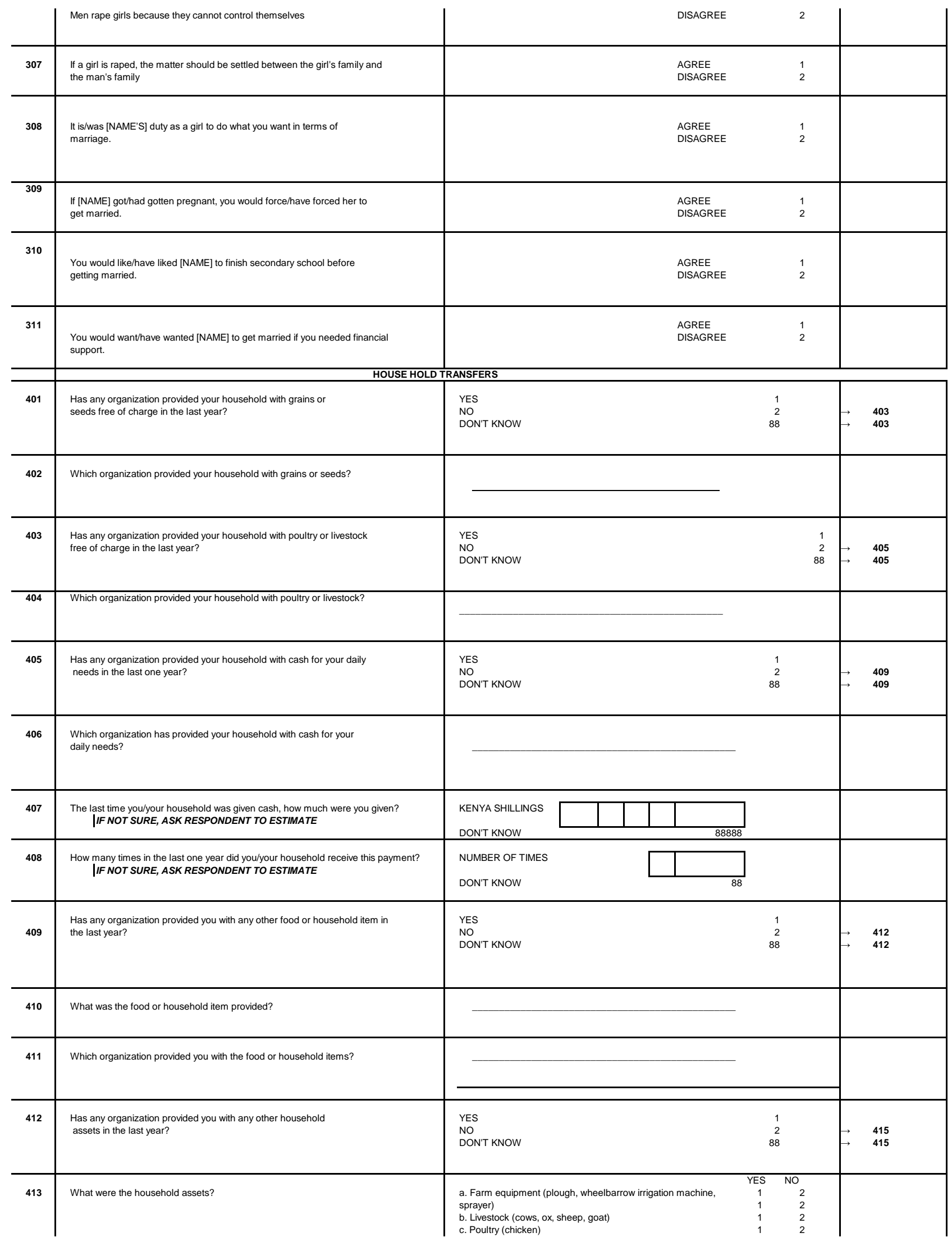




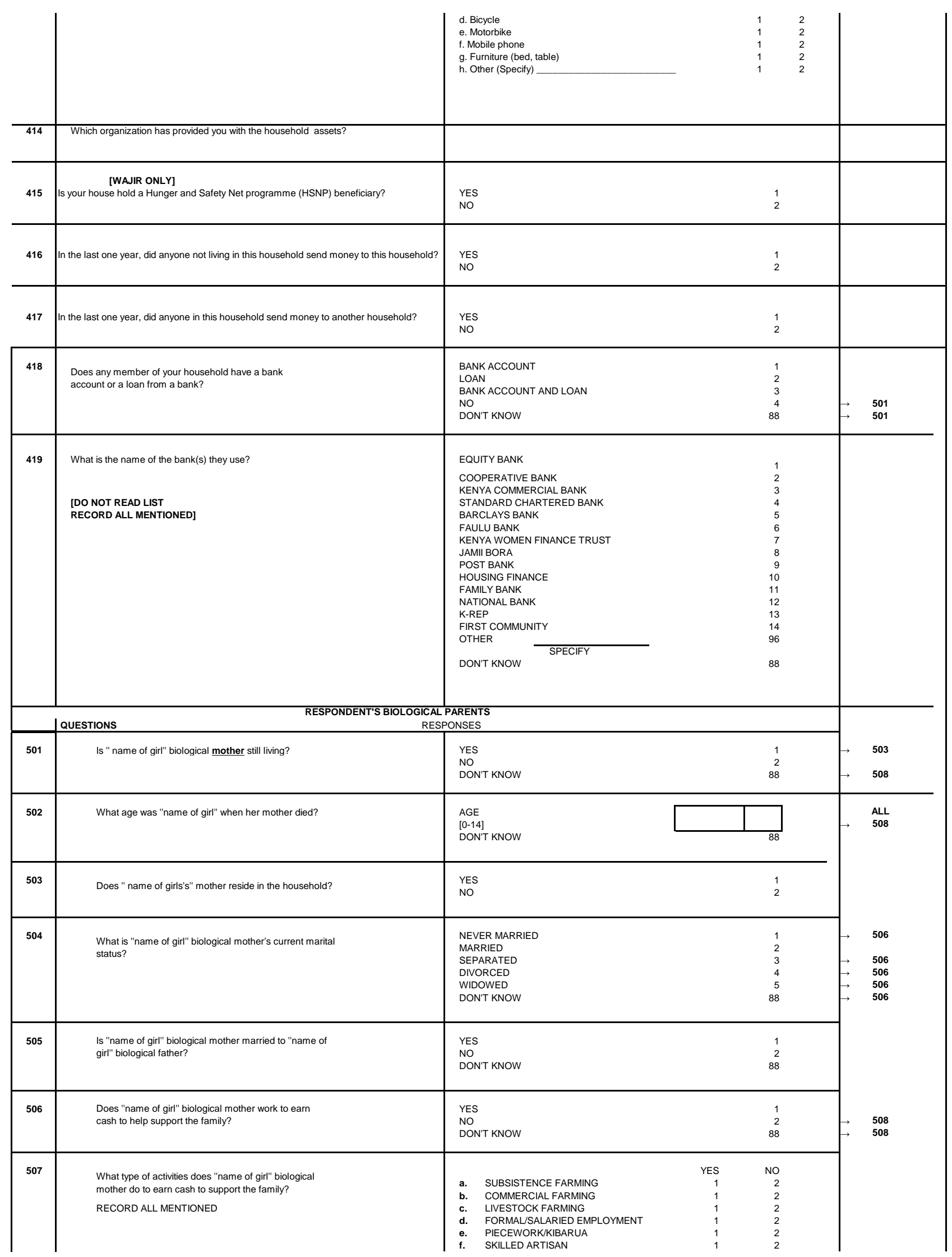




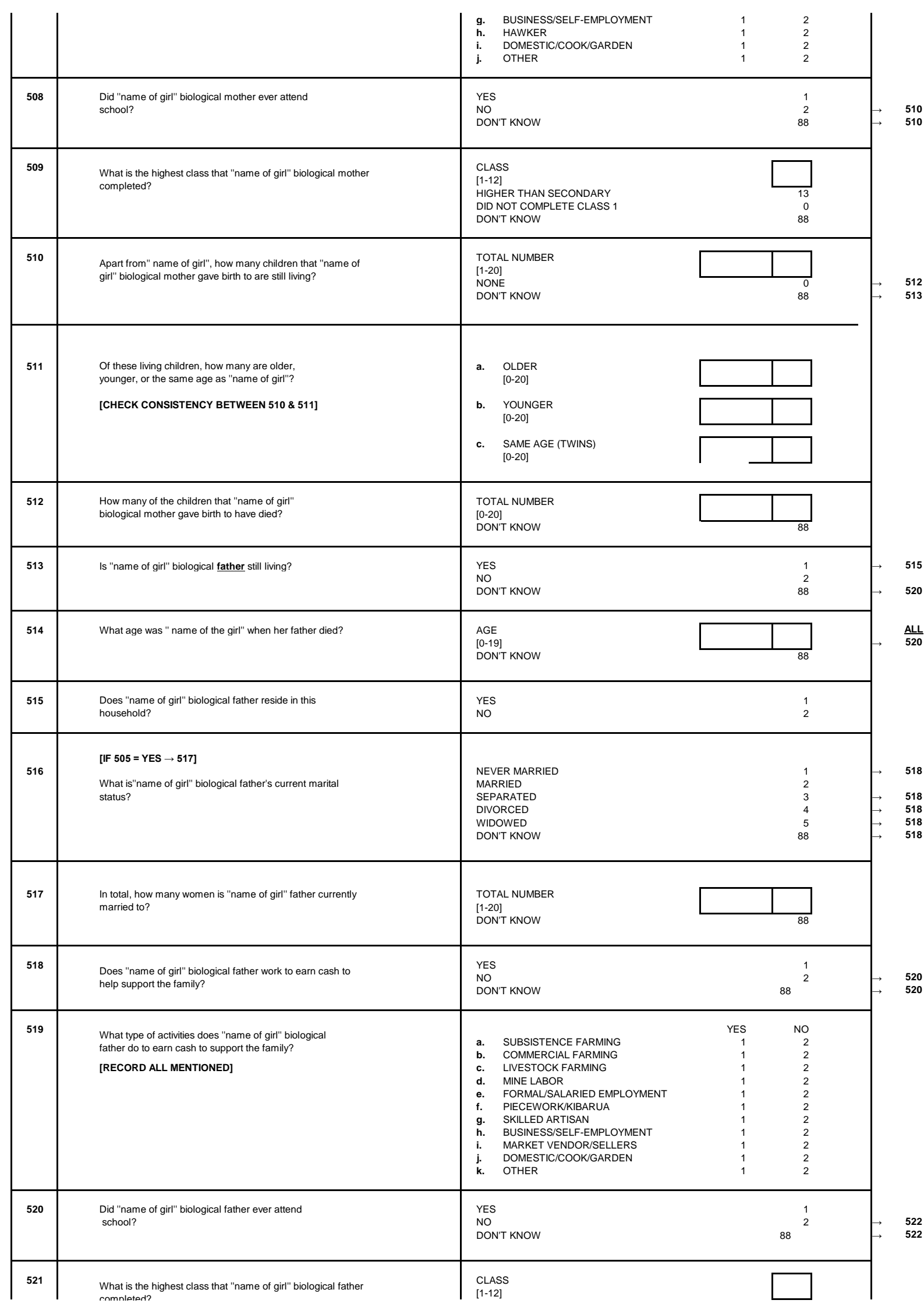




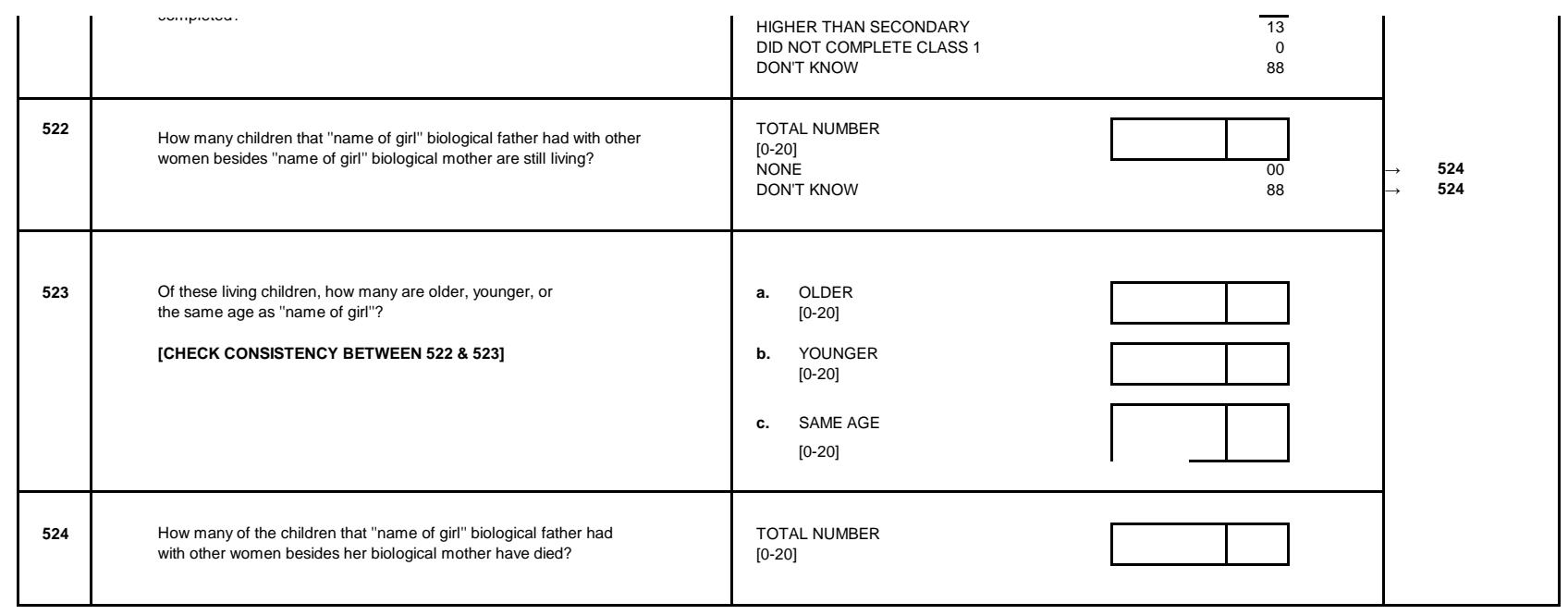

THANK YOU FOR YOUR TIME. NOW I WOULD LIKE TO TALK TO YOUR DAUGHTER/GIRL 
ENGLISH

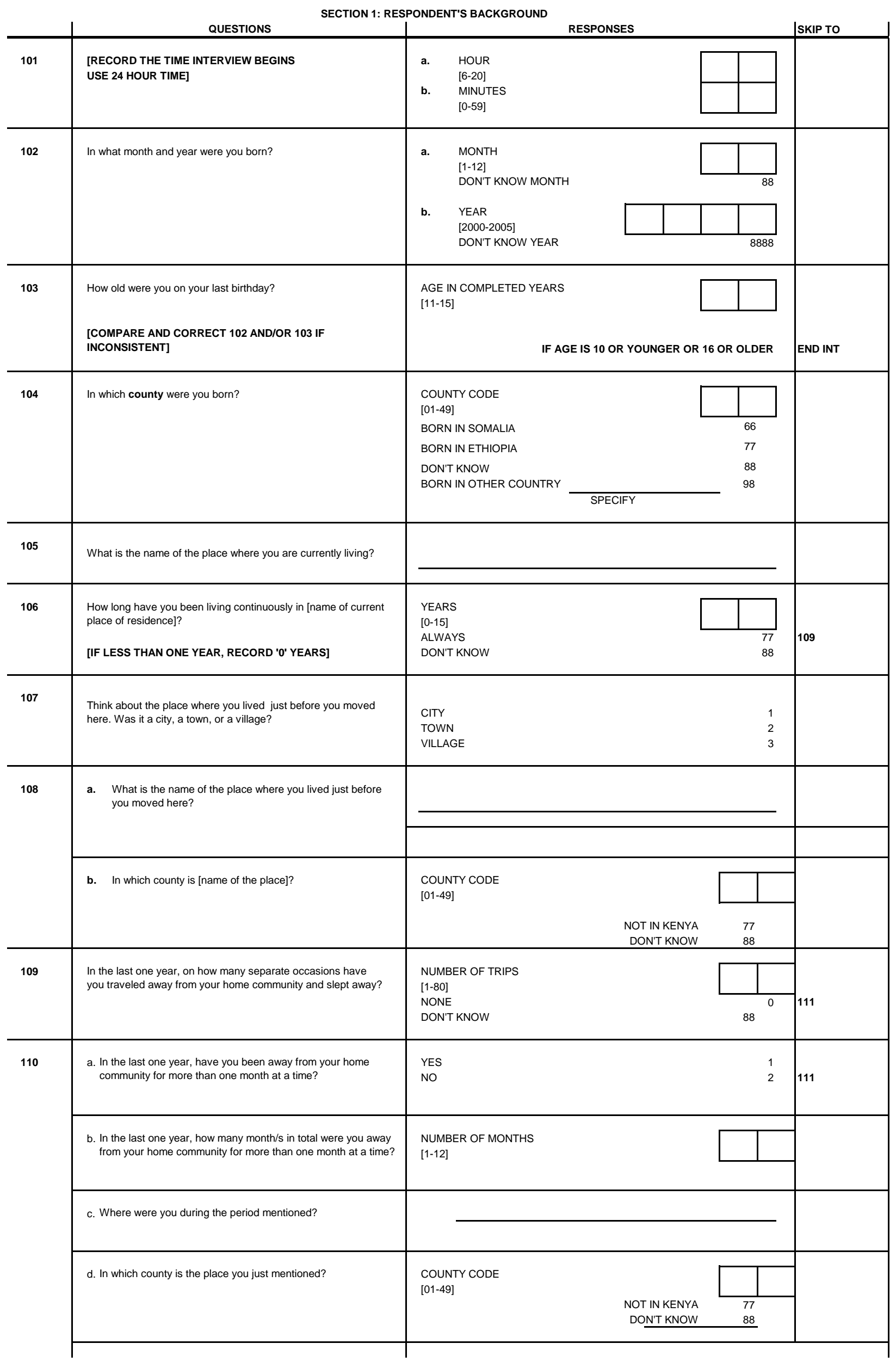




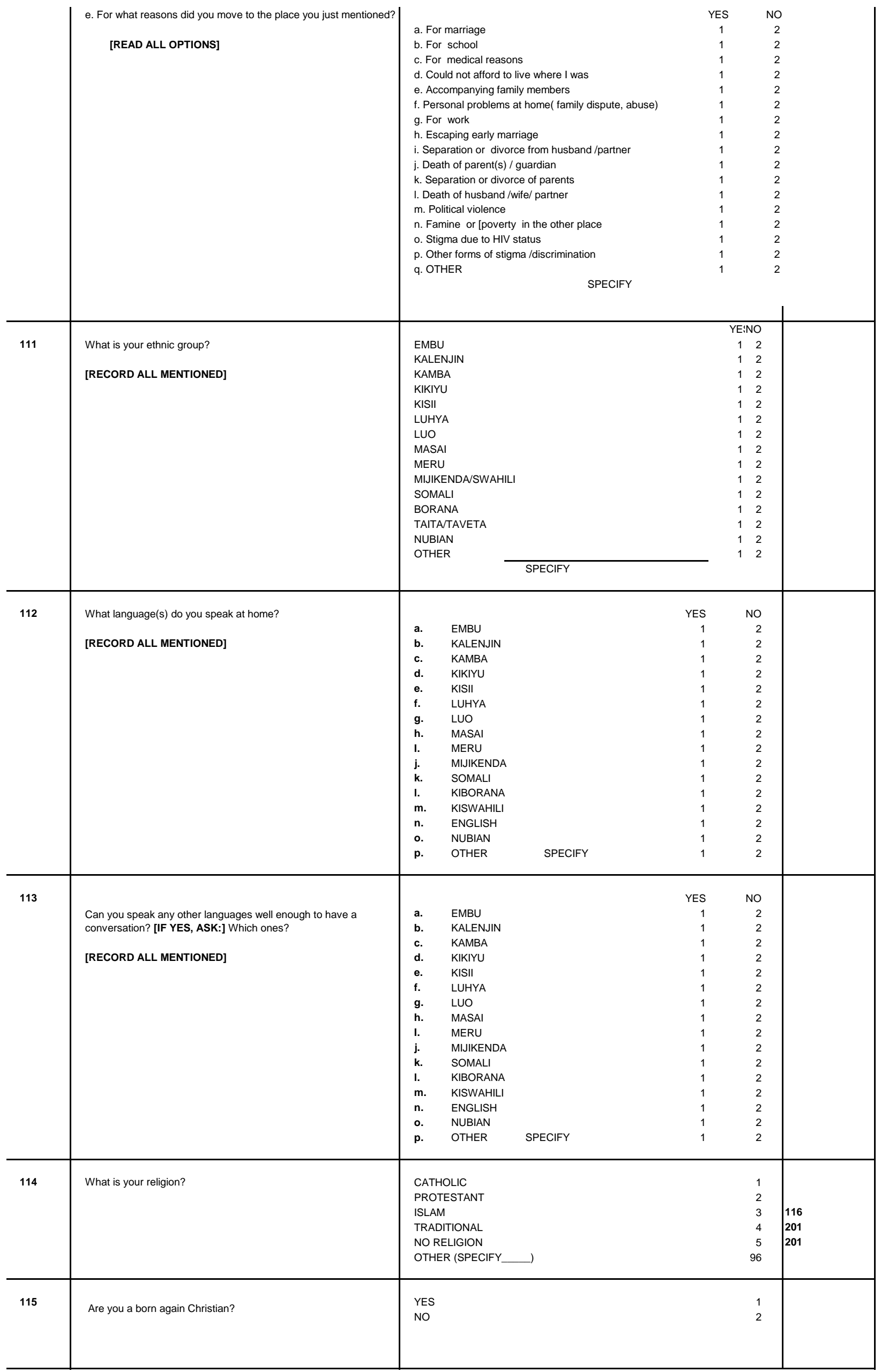




\begin{tabular}{|c|c|c|c|c|c|}
\hline 116 & $\begin{array}{l}\text { When was the last time you attended religious services at a } \\
\text { church or mosque? }\end{array}$ & $\begin{array}{l}\text { TODAY } \\
\text { IN THE LAST WEEK } \\
\text { IN THE LAST MONTH } \\
2-5 \text { MONTHS AGO } \\
6 \text { MONTHS OR MORE AGO } \\
\text { NEVER }\end{array}$ & & $\begin{array}{l}1 \\
2 \\
3 \\
4 \\
5\end{array}$ & 118 \\
\hline 117 & $\begin{array}{l}\text { What is the name (and denomination) of the church/mosque } \\
\text { you usually attend? What other church/mosque do you attend? } \\
\text { [RECORD ALL MENTIONED] }\end{array}$ & & & & \\
\hline 118 & $\begin{array}{l}\text { What other religious activities have you done in the last month? } \\
\text { [READ ALL OPTIONS] }\end{array}$ & $\begin{array}{ll}\text { a. } & \text { CHOIR } \\
\text { b. } & \text { YOUTH GROUP } \\
\text { c. } & \text { BIBLE/KORAN STUDY } \\
\text { d. } & \text { PRAYER MEETING } \\
\text { e. } & \text { VISITING THE SICK } \\
\text { f. } & \text { REVIVAL MEETINGS } \\
\text { g. } & \text { EVANGELICAL WORK } \\
\text { h. } & \text { ISLAMIC SCHOOL/MADRASSA } \\
\text { i. } & \text { NIGHT PRAYERS } \\
\text { j. } & \text { FASTING } \\
\text { k. } & \text { OFFERING } \\
\text { k. } & \text { OTHER (SPECIFY__ } \\
\text { l. } & \text { NONE }\end{array}$ & $\begin{array}{r}\text { YES } \\
1 \\
1 \\
1 \\
1 \\
1 \\
1 \\
1 \\
1 \\
1 \\
1 \\
1 \\
1 \\
1\end{array}$ & $\begin{array}{r}\text { NO } \\
2 \\
2 \\
2 \\
2 \\
2 \\
2 \\
2 \\
2 \\
2 \\
2 \\
2 \\
2 \\
2\end{array}$ & \\
\hline
\end{tabular}

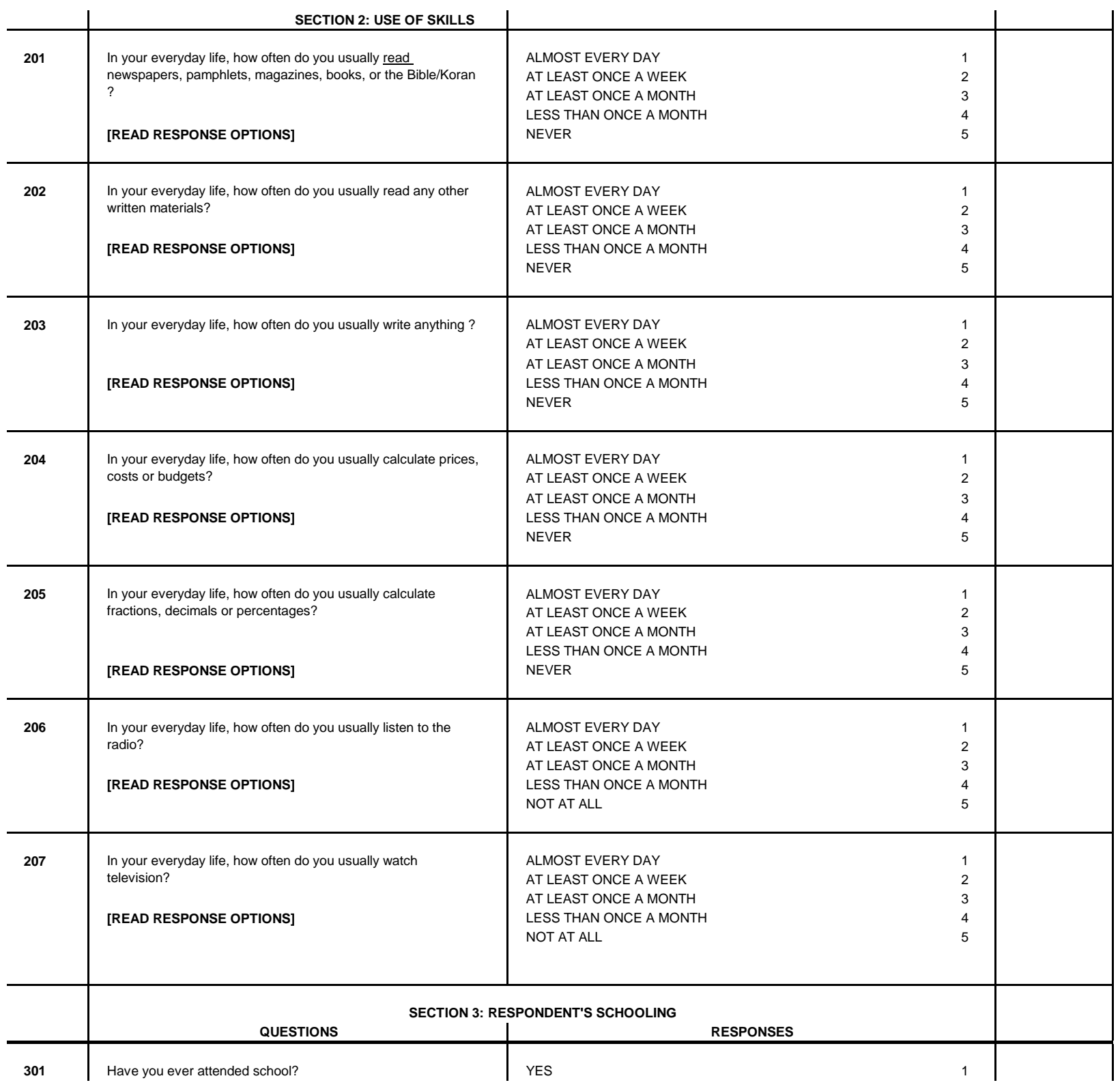




\begin{tabular}{|c|c|c|c|c|}
\hline & $\begin{array}{l}\text { [Clarify this does not include Duksi or } \\
\text { Madrassa] }\end{array}$ & NO & 2 & 401 \\
\hline 302 & At what age did you start Standard 1 ? & $\begin{array}{l}\text { AGE } \\
{[4-14]} \\
\text { DON'T KNOW }\end{array}$ & 88 & \\
\hline 303 & $\begin{array}{l}\text { Was the highest level of school you attended: primary OR } \\
\text { secondary? }\end{array}$ & $\begin{array}{l}\text { PRIMARY } \\
\text { SECONDARY }\end{array}$ & $\begin{array}{l}1 \\
2\end{array}$ & 305 \\
\hline 304 & What is the highest class you completed at primary school? & $\begin{array}{l}\text { STANDARD } \\
\text { [1-8] } \\
\text { DID NOT COMPLETE STANDARD } 1\end{array}$ & 0 & 306 \\
\hline 305 & What is the highest class you completed at secondary school? & $\begin{array}{l}\text { FORM } \\
\text { [1-4] } \\
\text { DID NOT COMPLETE FORM } 1\end{array}$ & 0 & 306 \\
\hline 306 & $\begin{array}{l}\text { [IF } \mathbf{3 0 4}<\mathbf{8} \rightarrow \mathbf{3 0 8}] \\
\text { Did you ever take the Kenya Certificate of Primary Education } \\
\text { (KCPE)? }\end{array}$ & $\begin{array}{l}\text { YES } \\
\text { NO }\end{array}$ & $\begin{array}{l}1 \\
2\end{array}$ & 308 \\
\hline 307 & What were your KCPE marks? & $\begin{array}{l}\text { MARKS } \\
{[0-888]} \\
\text { DON'T KNOW }\end{array}$ & 888 & \\
\hline 308 & Have you ever attended a trade or vocational school? & $\begin{array}{l}\text { YES } \\
\text { NO }\end{array}$ & $\begin{array}{l}1 \\
2\end{array}$ & \\
\hline 309 & $\begin{array}{l}\text { Have you attended school at any time during [the 2015/this] } \\
\text { school year? }\end{array}$ & $\begin{array}{l}\text { YES } \\
\text { NO }\end{array}$ & $\begin{array}{l}1 \\
2\end{array}$ & 312 \\
\hline 310 & At what age did you stop attending school? & $\begin{array}{l}\text { AGE } \\
{[4-15]} \\
\text { DON'T KNOW }\end{array}$ & 88 & \\
\hline 311 & $\begin{array}{l}\text { What are the reasons you left school when you did? } \\
\text { [DO NOT READ LIST, CHECK ALL MENTIONED] }\end{array}$ & $\begin{array}{l}\text { SCHOOL ISSUES } \\
\text { Waiting for KCPE/KCSE Results } \\
\text { Going to new school this term } \\
\text { Finished primary school } \\
\text { Not selected to secondary school } \\
\text { Finished secondary school } \\
\text { Not doing well at school } \\
\text { Don't like school/rather do something else } \\
\text { Problems with/afraid of other students } \\
\text { Problems with/afraid of teacher } \\
\text { Travel/distance to school } \\
\text { Parents/guardian don't want } \\
\text { FINANCIAL/WORK } \\
\text { Financial/Costs } \\
\text { No money for development funds } \\
\text { Need to work at home/fields/livestock } \\
\text { Need to work/earn money } \\
\text { MARRIAGE/BIRTH } \\
\text { Marriage } \\
\text { Pregnancy } \\
\text { Has baby/nursing baby } \\
\text { ILLNESS/DEATH } \\
\text { Respondent sick/ill } \\
\text { Illness of HH member } \\
\text { Death of HH member } \\
\text { HOUSEHOLD ISSUES } \\
\text { Need to look after brothers/sisters } \\
\text { OTHER ISSUES } \\
\text { Other (specify)__ }\end{array}$ & $\begin{array}{r}1 \\
2 \\
3 \\
4 \\
5 \\
6 \\
7 \\
8 \\
9 \\
10 \\
11 \\
\\
12 \\
13 \\
14 \\
15 \\
\\
16 \\
17 \\
18 \\
\\
18 \\
19 \\
20 \\
\\
21 \\
\end{array}$ & $\frac{A L L}{330}$ \\
\hline 312 & What is the name of the school you attend? & & & \\
\hline 313 & Is this a primary or a secondary or vocational school? & $\begin{array}{l}\text { PRIMARY } \\
\text { SECONDARY } \\
\text { TRADE/VOCATIONAL }\end{array}$ & $\begin{array}{l}1 \\
2 \\
3\end{array}$ & $\begin{array}{l}315 \\
318\end{array}$ \\
\hline
\end{tabular}




\section{6}

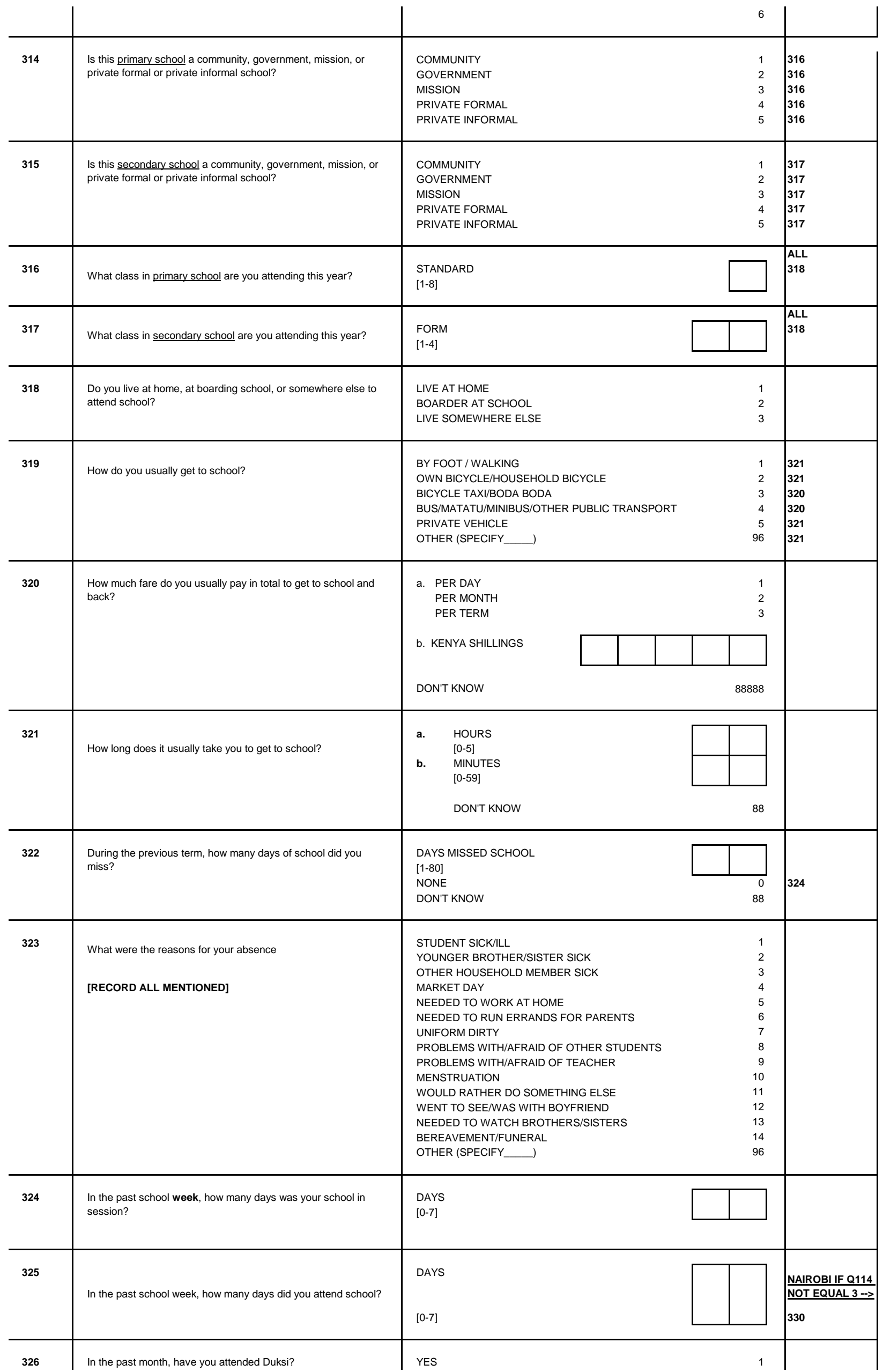




\begin{tabular}{|c|c|c|c|c|}
\hline & & NO & 2 & 328 \\
\hline 327 & $\begin{array}{l}\text { When you attended Duksi, how many days per week did you } \\
\text { attend, and how many hours each day? }\end{array}$ & $\begin{array}{l}\text { A. DAYS } \\
{[0-7]}\end{array}$ & & \\
\hline & & $\begin{array}{l}\text { B. HOURS } \\
{[0-12]}\end{array}$ & & \\
\hline 328 & In the past month, have you attended Madrassa? & $\begin{array}{l}\text { YES } \\
\text { NO }\end{array}$ & $\begin{array}{l}1 \\
2\end{array}$ & 330 \\
\hline 329 & $\begin{array}{l}\text { When you attended Madrassa, how many days per week did } \\
\text { you attend, and how many hours each day? }\end{array}$ & $\begin{array}{l}\text { A. DAYS } \\
{[0-7]}\end{array}$ & & \\
\hline & & $\begin{array}{l}\text { B. HOURS } \\
{[0-12]}\end{array}$ & & \\
\hline 330 & $\begin{array}{l}\text { Now I would like to ask about each of the schools and grades } \\
\text { you have attended. }\end{array}$ & FILL IN SCHOOLING HISTORY SHEET & & \\
\hline
\end{tabular}

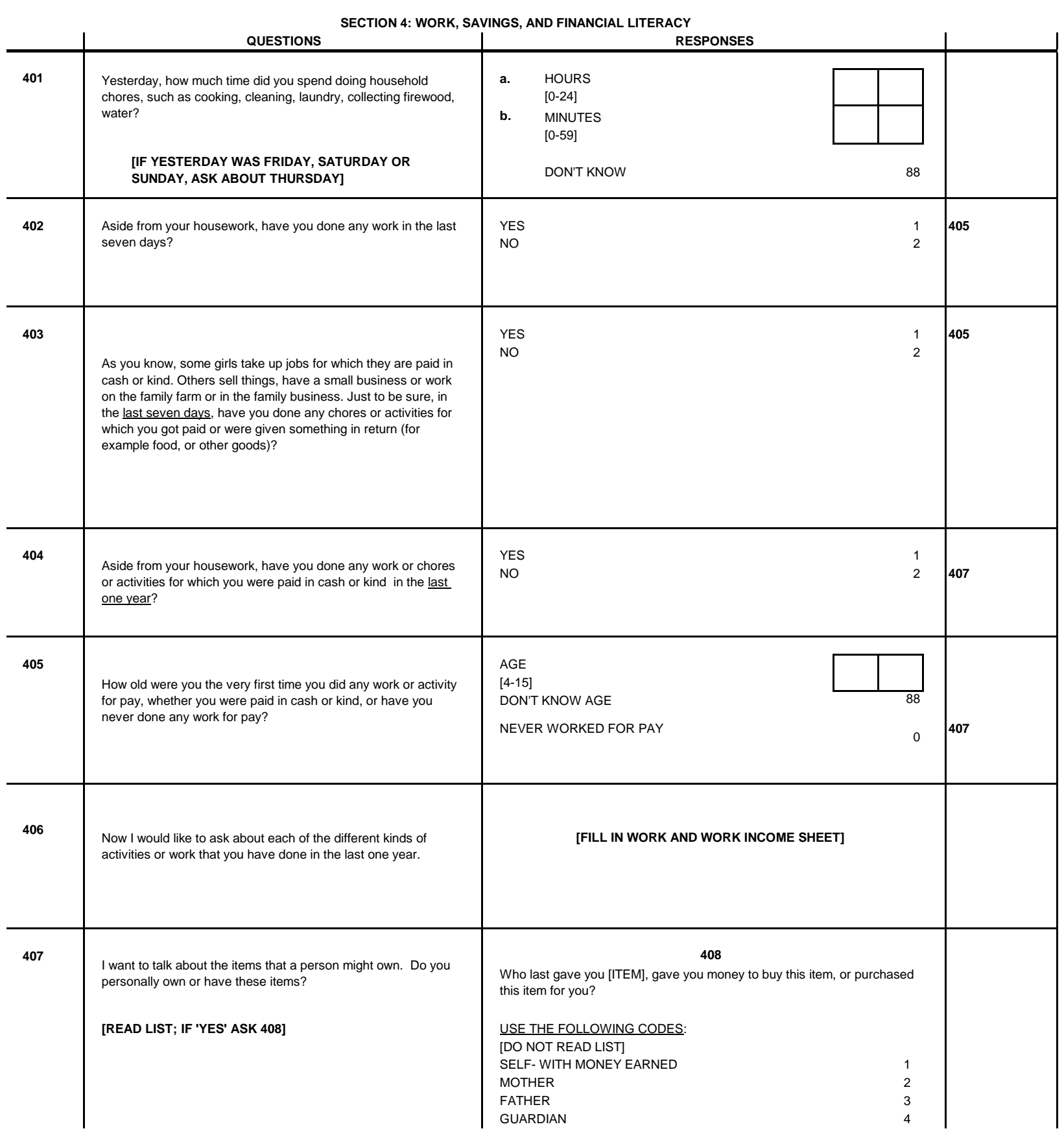


b. A PAIR OF SHOES

BOYFRIEND

HUSBAND

SUGAR DADDY

MALE FRIEND

FEMALE FRIEND

OTHER RELATIVE

TEACHER

OTHER (SPECIFY)

CODE

a. A BLANKET

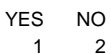

a. A BLANKET

c. SCHOOL UNIFORM

1

b. A PAIR OF SHOES

d. TWO SETS OF CLOTHES (OTHER

$\begin{array}{llll}1 & 2 & \text { c. } & \text { SCHOOL UNIFORM }\end{array}$ THAN UNIFORM)

d.

TWO SETS OF CLOTHES (OTHER THAN UNIFORM)

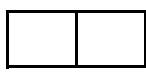

e. ASCHOOL BAG

e. A SCHOOL BAG

f. SOME JEWELRY

g. HAIR CLIPS/RIBBONS

h. A MOBILE TELEPHONE

ASCHOOLBAG

\begin{tabular}{ll|l}
1 & 2 & f.
\end{tabular}

g. HAIR CLIPS/RIBBONS

1

$\begin{array}{lll}12 & \text { h. A MOBILE TELEPHONE }\end{array}$

i. A CLOCK OR A WRIST WATCH

i. A CLOCK OR A WRIST WATCH

j. A BICYCLE

12
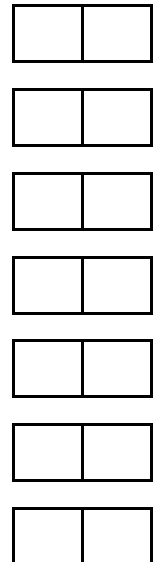

j. $A B I C Y C L E$

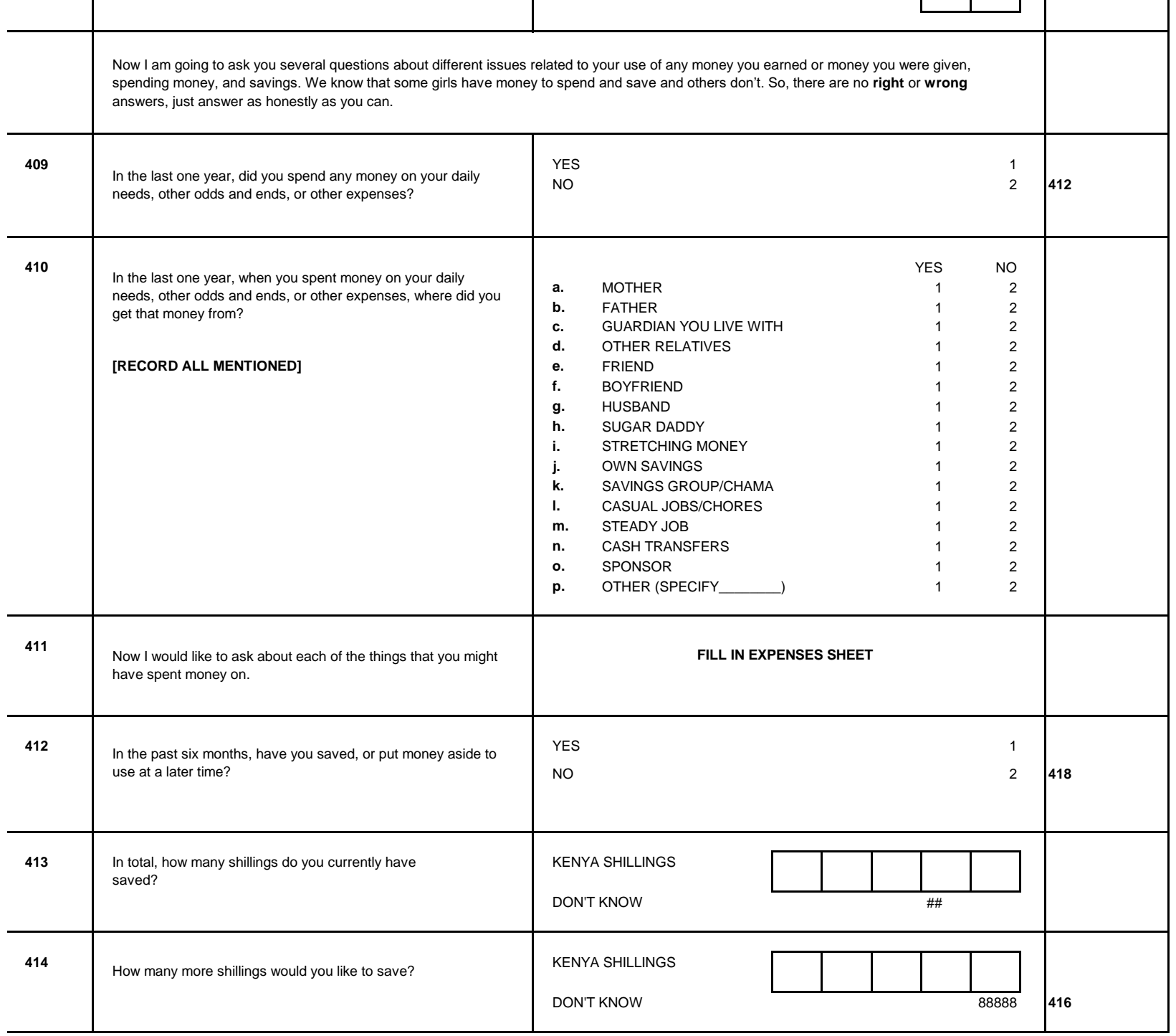




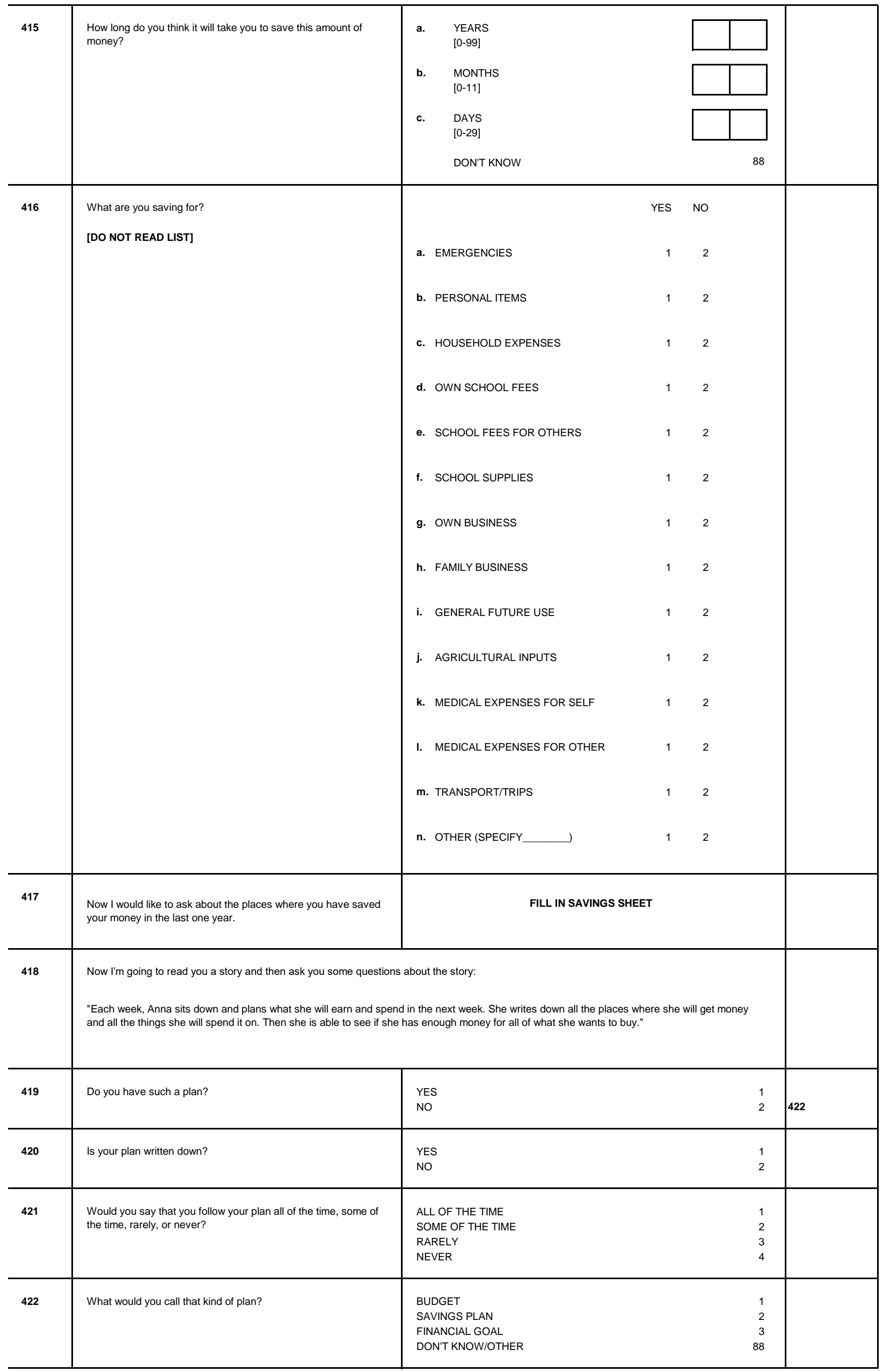




\begin{tabular}{|c|c|c|c|}
\hline 423 & \multicolumn{3}{|c|}{$\begin{array}{l}\text { Now I'm going to read you another story and then ask you some questions about it: } \\
\text { 'Imani is } 17 \text { and and lives with her mother and her younger sister. Her older sister Mary is married and lives in another town, three hours away. } \\
\text { Mary just had a baby boy, and Imani is eager to visit her sister. Imani will need to save money for transport and a small gift for the baby. A cute } \\
\text { little hat would be perfect! But she can't take money from her savings because she is saving that money to start her own business. Imani's dream } \\
\text { is to start a small catering business. Hopefully, her neighbor will employ her to work extra days in her hotel so she can get the money she needs } \\
\text { for her trip." }\end{array}$} \\
\hline 424 & What is one of Imani's short term financial goals? & $\begin{array}{l}\text { TRANSPORT TO VISIT HER SISTER } \\
\text { BUY A GIFT FOR HER NEPHEW } \\
\text { START A BUSINESS } \\
\text { OTHER } \\
\text { DON'T KNOW }\end{array}$ & $\begin{array}{r}1 \\
2 \\
3 \\
4 \\
88\end{array}$ \\
\hline 425 & What is Imani's long term financial goal? & $\begin{array}{l}\text { TRANSPORT TO VISIT HER SISTER } \\
\text { BUY A GIFT FOR HER NEPHEW } \\
\text { START A BUSINESS } \\
\text { OTHER } \\
\text { DON'T KNOW }\end{array}$ & $\begin{array}{r}1 \\
2 \\
3 \\
4 \\
88\end{array}$ \\
\hline 426 & What is one formal way of saving your money? & $\begin{array}{l}\text { BANK/BANK ACCOUNT } \\
\text { SAVINGS ACCOUNT } \\
\text { HOMEBANK/UNDER MATTRESS/HOLE } \\
\text { BOX/CLOSET } \\
\text { WITH A FRIEND } \\
\text { WITH A PARENT OR GUARDIAN } \\
\text { IN A SAVINGS GROUP/CHAMA } \\
\text { SHOPKEEPER } \\
\text { INVESTMENTS } \\
\text { MPESA } \\
\text { DON'T KNOW }\end{array}$ & $\begin{array}{r}1 \\
2 \\
3 \\
4 \\
5 \\
7 \\
8 \\
9 \\
10 \\
11 \\
88\end{array}$ \\
\hline 427 & What is one informal way of saving your money? & $\begin{array}{l}\text { BANK/BANK ACCOUNT } \\
\text { SAVINGS ACCOUNT } \\
\text { HOMEBANK/UNDER MATTRESS/HOLE } \\
\text { BOX/CLOSET } \\
\text { WITH A FRIEND } \\
\text { WITH A PARENT OR GUARDIAN } \\
\text { IN A SAVINGS GROUP/CHAMA } \\
\text { SHOPKEEPER } \\
\text { INVESTMENTS } \\
\text { MPESA } \\
\text { DON'T KNOW }\end{array}$ & $\begin{array}{r}1 \\
2 \\
3 \\
4 \\
5 \\
7 \\
8 \\
9 \\
10 \\
11 \\
88\end{array}$ \\
\hline 428 & $\begin{array}{l}\text { Grace would like to buy a new notebook for the next school } \\
\text { term which starts in eight weeks. If the notebook costs KSH } 100 \\
\text { and she can save KSH10 each week, will she reach her goal? }\end{array}$ & $\begin{array}{l}\text { YES } \\
\text { NO }\end{array}$ & $\begin{array}{l}1 \\
2\end{array}$ \\
\hline 429 & $\begin{array}{l}\text { In the situation I described in the previous question, if Grace } \\
\text { figured out how much she needed to save each week, and for } \\
\text { how many weeks she needed to save in order to reach her } \\
\text { goal, what would that be called? }\end{array}$ & $\begin{array}{l}\text { BUDGET } \\
\text { SAVINGS PLAN } \\
\text { FINANCIAL GOAL } \\
\text { DON'T KNOW }\end{array}$ & $\begin{array}{r}1 \\
2 \\
3 \\
88\end{array}$ \\
\hline 430 & $\begin{array}{l}\text { If Grace discovered that she couldn't reach her goal with that } \\
\text { plan, what changes could she make so she would still reach } \\
\text { her goal? }\end{array}$ & $\begin{array}{l}\text { BUY A CHEAPER NOTEBOOK } \\
\text { SAVE MORE EACH WEEK } \\
\text { GIVE HERSELF LONGER TIME TO REACH HER GOAL } \\
\text { OTHER } \\
\text { DON'T KNOW }\end{array}$ & $\begin{array}{r}1 \\
2 \\
3 \\
4 \\
88\end{array}$ \\
\hline 431 & $\begin{array}{l}\text { Do you agree or disagree with the following statement: "Only } \\
\text { people with a lot of money can save"? }\end{array}$ & $\begin{array}{l}\text { AGREE } \\
\text { DISAGREE }\end{array}$ & $\begin{array}{l}1 \\
2\end{array}$ \\
\hline 432 & $\begin{array}{l}\text { If you could only spend money on one of the following, which } \\
\text { would it be? } \\
\text { [READ ALL OPTIONS] }\end{array}$ & $\begin{array}{l}\text { SWEETS } \\
\text { FOOD } \\
\text { A NEW DRESS }\end{array}$ & $\begin{array}{l}1 \\
2 \\
3\end{array}$ \\
\hline 433 & $\begin{array}{l}\text { When there are weeks, for example, when you have met all } \\
\text { your basic needs and at the end of the week you still have KSH } \\
50 \text { remaining, what do you usually do with that money? }\end{array}$ & $\begin{array}{l}\text { SAVE/PUT ASIDE FOR FUTURE USE } \\
\text { BUY SOMETHING EXTRA } \\
\text { DON'T KNOW }\end{array}$ & $\begin{array}{r}1 \\
2 \\
88\end{array}$ \\
\hline
\end{tabular}




\begin{tabular}{|c|c|c|c|c|c|c|c|c|c|c|}
\hline \multirow{11}{*}{501} & \multicolumn{10}{|c|}{ SECTION 5: SOCIAL CAPITAL AND NETWORKS } \\
\hline & \multicolumn{3}{|c|}{$\begin{array}{l}\text { Are you a member of any social groups or clubs? For instance, } \\
\text { are you a member of ...? }\end{array}$} & \multicolumn{4}{|c|}{$\begin{array}{l}\quad 502 \\
\text { When is the last time you attended } \\
\text { this club? }\end{array}$} & \multicolumn{3}{|c|}{$\begin{array}{l}\quad 503 \\
\text { Was it a girls only club or } \\
\text { mixed girls and boys? }\end{array}$} \\
\hline & & YES & NO & & $\begin{array}{l}\text { LAST } 7 \\
\text { DAYS }\end{array}$ & $\begin{array}{l}\text { LAST } \\
\text { MONTH }\end{array}$ & $\begin{array}{l}\text { IN THE LAST } \\
\text { ONE YEAR }\end{array}$ & & & Mixed \\
\hline & a. Gender club & 1 & 2 & a. & 1 & 2 & 3 & a. & 1 & 2 \\
\hline & b. Child rights/Human rights & 1 & 2 & b. & 1 & 2 & 3 & b. & 1 & 2 \\
\hline & $\begin{array}{l}\text { c. HIV\&AIDS/Health life skills/ } \\
\text { Guidance \& counseling club }\end{array}$ & 1 & 2 & c. & 1 & 2 & 3 & c. & 1 & 2 \\
\hline & d. Girl guides/scouts & 1 & 2 & d. & 1 & 2 & 3 & d. & 1 & 2 \\
\hline & e. Sports club & 1 & 2 & e. & 1 & 2 & 3 & e. & 1 & 2 \\
\hline & f. Drama or dancing group & 1 & 2 & f. & 1 & 2 & 3 & f. & 1 & 2 \\
\hline & g. Church group/Muslim group & 1 & 2 & g. & 1 & 2 & 3 & g. & 1 & 2 \\
\hline & h. Any other & 1 & 2 & h. & 1 & 2 & 3 & h. & 1 & 2 \\
\hline
\end{tabular}

[FIRST ASK ALL QUESTIONS FOR MALES AND RECORD ANSWERS IN COLUMN A; THEN RETURN TO ASK ALL QUESTIONS FOR FEMALES AND RECORD ANSWERS IN COLUMN B]

Now I want to ask about your good friends. What we mean by a good friend is someone you can confide in about personal matters and share important information.

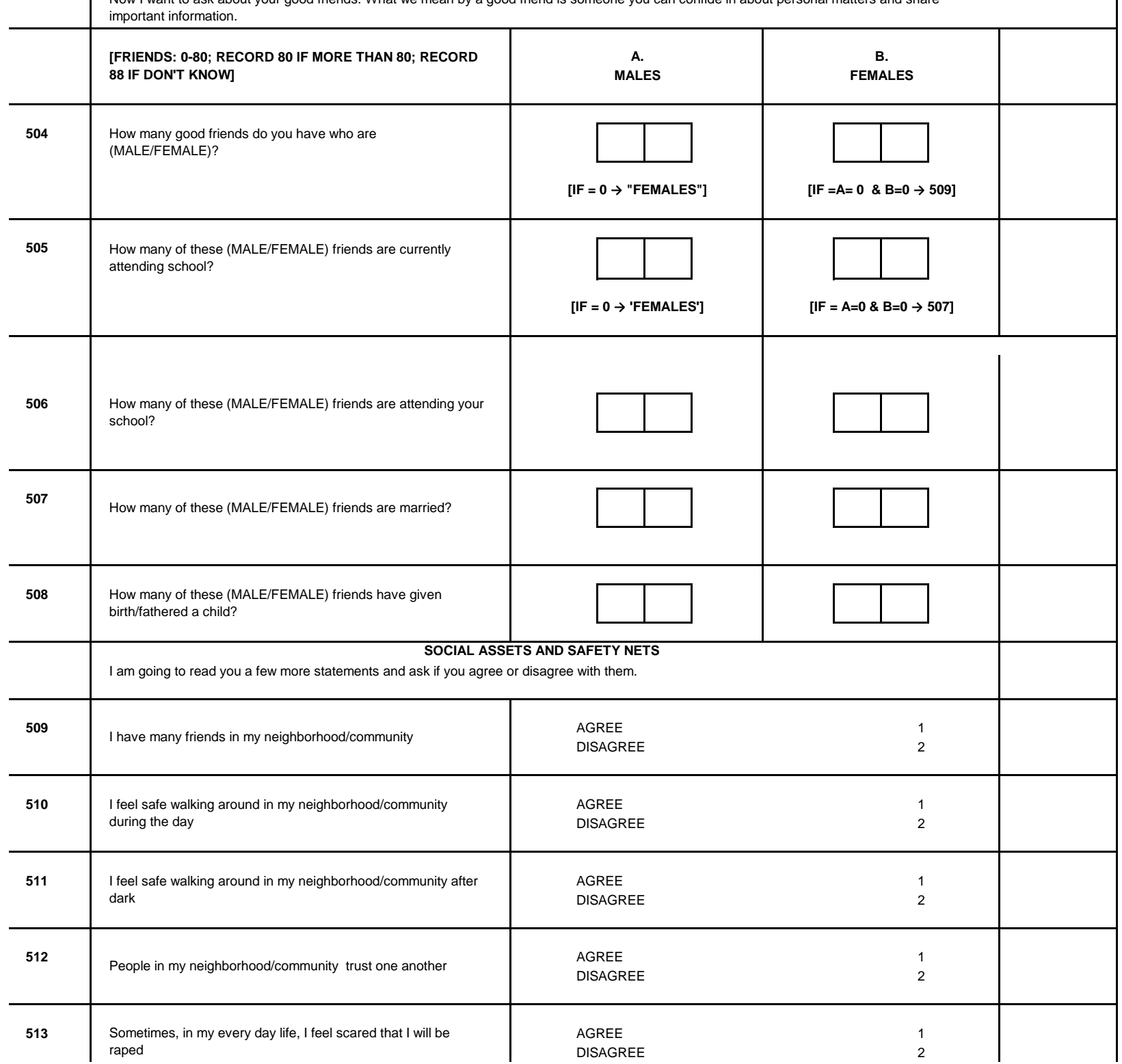




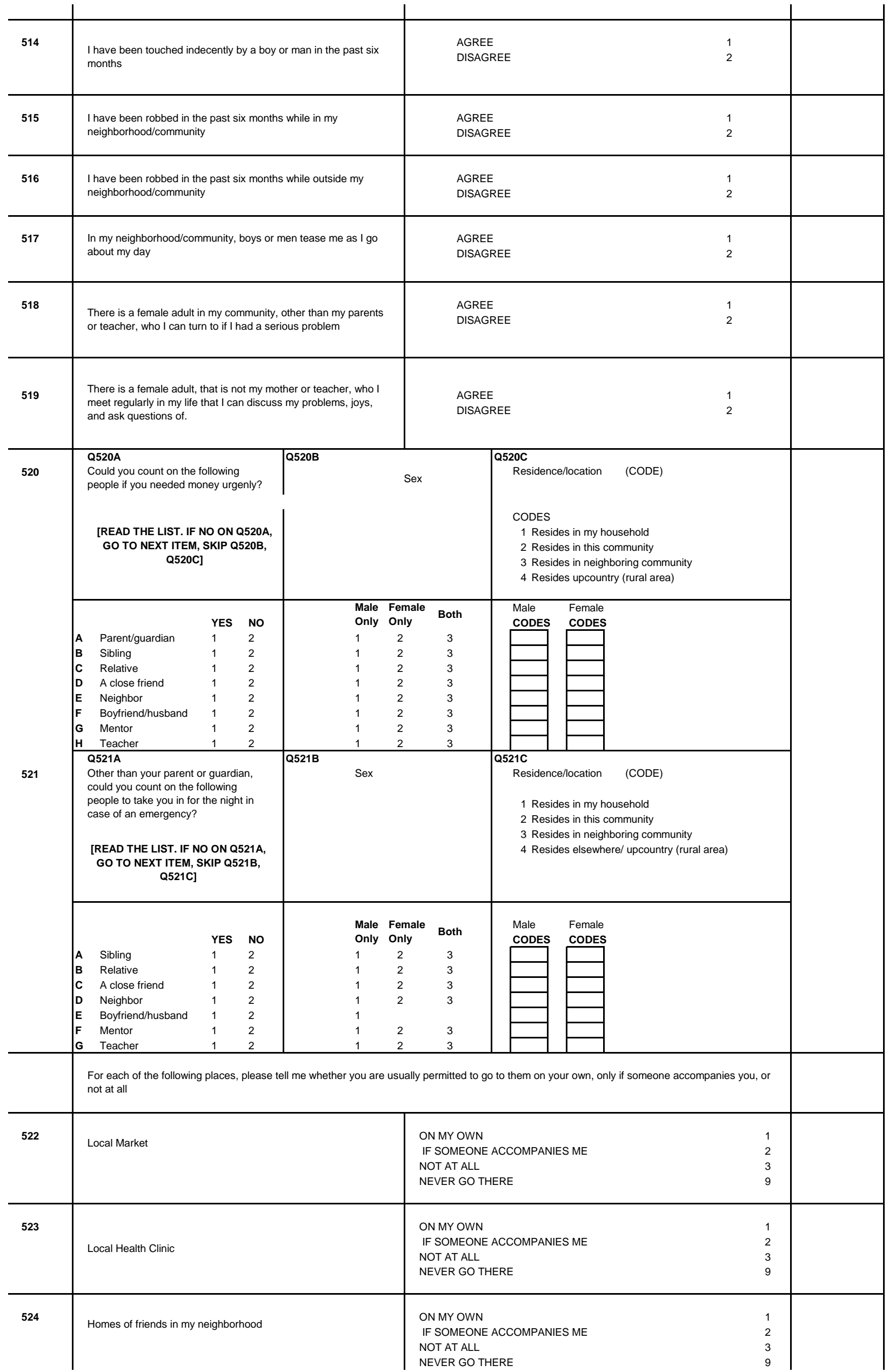




\begin{tabular}{|c|l|} 
& \\
1 & \\
2 & \\
3 & \\
9 & \\
\hline 1 & \\
2 & \\
3 & \\
9 & \\
\hline & \\
2 & \\
3 & \\
9 & \\
\hline & \\
& \\
\hline and try &
\end{tabular}

I want you to think about your most recent weekday, from Monday through Friday, that was not a public holiday or a school holiday and try to recall the different activities you did on that day. Tell me about the different activities you did and how long you spent on them.

IF SOMEONE ACCOMPANIES ME

NOT AT ALL

\begin{tabular}{|c|c|c|c|}
\hline 525 & School & $\begin{array}{l}\text { ON MY OWN } \\
\text { IF SOMEONE ACCOMPANIES ME } \\
\text { NOT AT ALL } \\
\text { NEVER GO THERE }\end{array}$ & $\begin{array}{l}1 \\
2 \\
3 \\
9\end{array}$ \\
\hline 526 & Work/Business & $\begin{array}{l}\text { ON MY OWN } \\
\text { IF SOMEONE ACCOMPANIES ME } \\
\text { NOT AT ALL } \\
\text { NEVER GO THERE }\end{array}$ & $\begin{array}{l}1 \\
2 \\
3 \\
9\end{array}$ \\
\hline 527 & Youth Group/Girls Group & $\begin{array}{l}\text { ON MY OWN } \\
\text { IF SOMEONE ACCOMPANIES ME } \\
\text { NOT AT ALL } \\
\text { NEVER GO THERE }\end{array}$ & $\begin{array}{l}1 \\
2 \\
3 \\
9\end{array}$ \\
\hline 528 & $\begin{array}{l}\text { I want you to think abol } \\
\text { to recall the different ac }\end{array}$ & $\begin{array}{l}\text { ough Friday, that was not a pub } \\
\text { different activities you did and }\end{array}$ & \\
\hline
\end{tabular}

ACTIVITY

[RECORD HOW MANY HOURS SHE SPENT ON VARIOUS ACTIVITIES DURING THE LAST COMPLETE WEEKDAY - NOT SATURDAY OR SUNDAY OR HOLIDAY.]

a. In school b. Unpaid work at home (e.g. cooking, cleaning, washing clothes)

c. Unpaid work outside the home (e.g. going to the market, fetching water)

d. Paid wage work/ paid work for others/ln own business

e. Leisure time (chatting with friends, drinking tea/coffee with friends, reading, watching TV

f. Church/mosque/praying/duksi/madrassa

g. TOTAL HOURS [CHECK NOT MORE THAN 24]
NUMBER OF HOURS
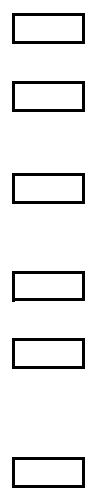

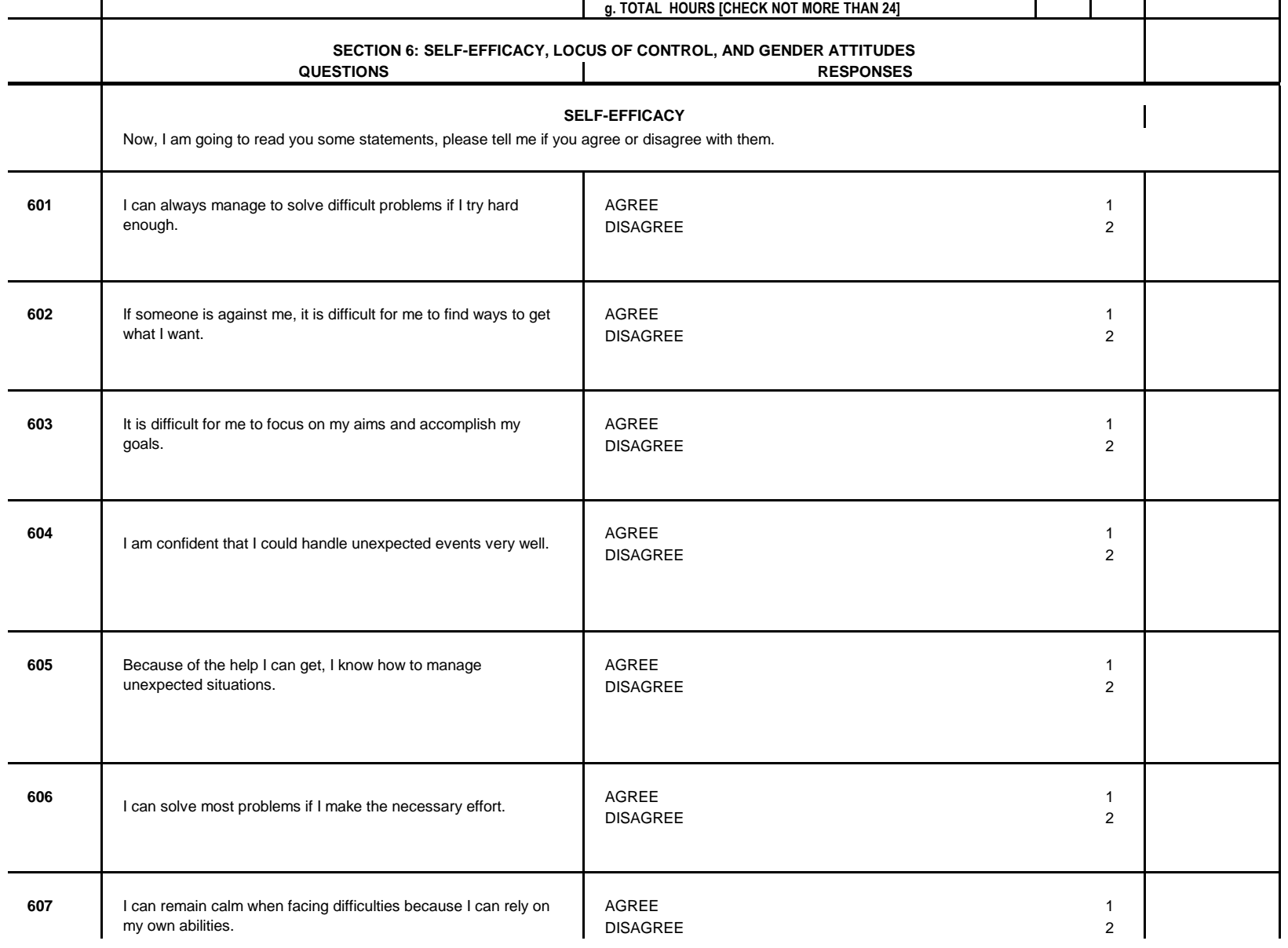




\begin{tabular}{|l|l|} 
& \\
\hline 1 & \\
2 & \\
\hline 1 & \\
2 & \\
\hline 1 & \\
2 & \\
\hline
\end{tabular}

LOCUS OF CONTROL

Now, I am going to read you two statements at a time, please tell me which of the two statements best reflects how you feel about yourself.

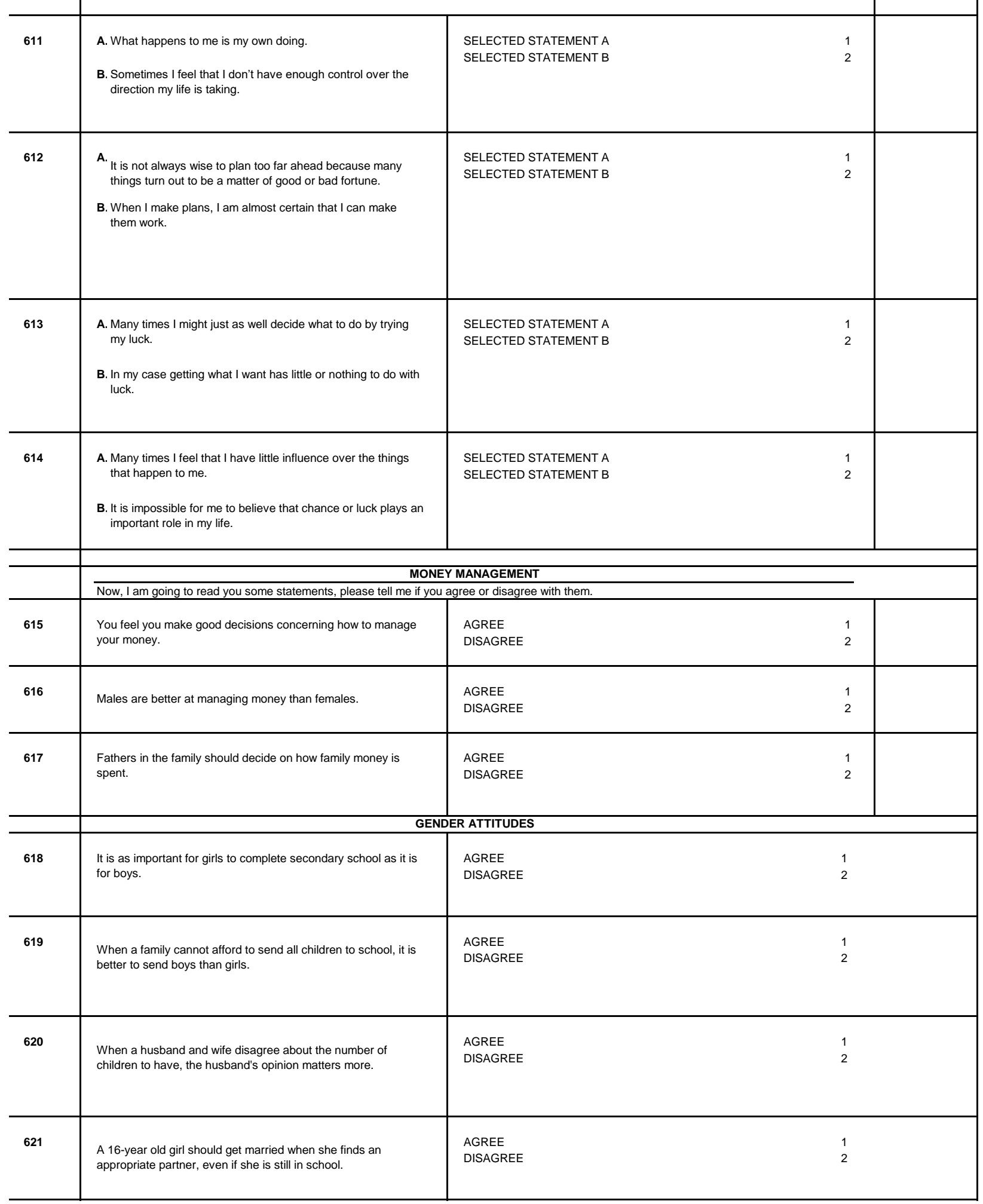




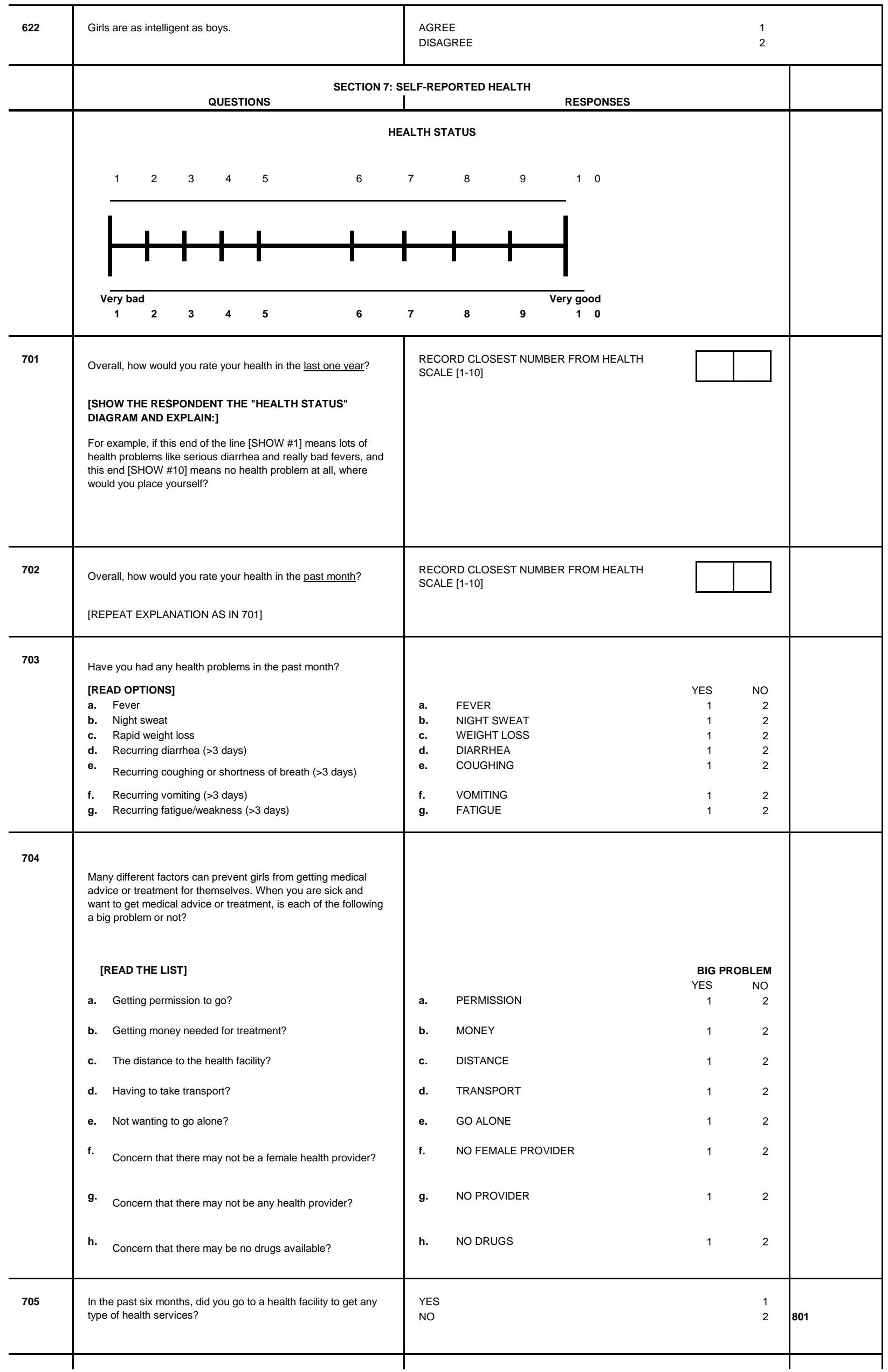


Please tell me which health services you received during those visits?

Which of the following health facilities did you visit in the past six months?

PUBLIC HOSPITAL

PRIVATE HOSPITAL

MISSION HOSPITAL

PUBLIC HEALTH CLINIC

PRIVATE HEALTH CLINIC

Read the list, Check

MISSION HEALTH CLINIC

NGO CLINIC

TRADITIONAL HEALER

PHARMACY

OTHER (SPECIFY

SERVICE CODES

a. GENERAL HEALTH/ SICKNESS

b. FAMILY PLANNING

c. PREGNANCY TEST

d. ANTENATAL CARE

e. HIV TESTING

f. HIV CARE/TREATMENT

g. STI TESTING (NON-HIV)

h. STI CARE/TREATMENT ( NON-HIV)

i. CHILD HEALTH/SICKNESS

j. DELIVERY

k. POSTNATAL CARE

I. OTHER REPRODUCTIVE HEALTH

SERVICES

m. PHARMACY/VITAMINS/MEDICINE

O. OTHER (SPECIFY)

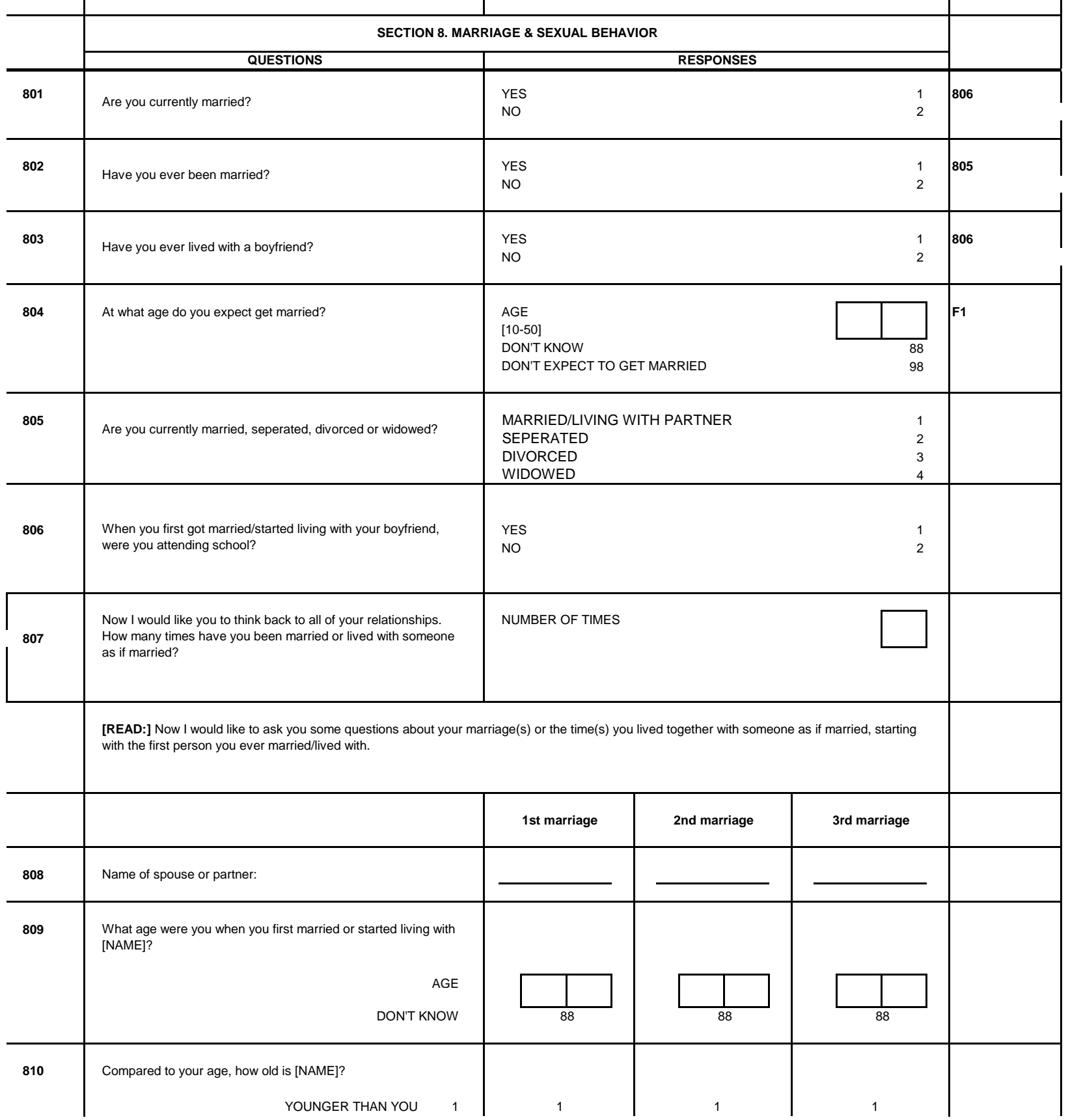




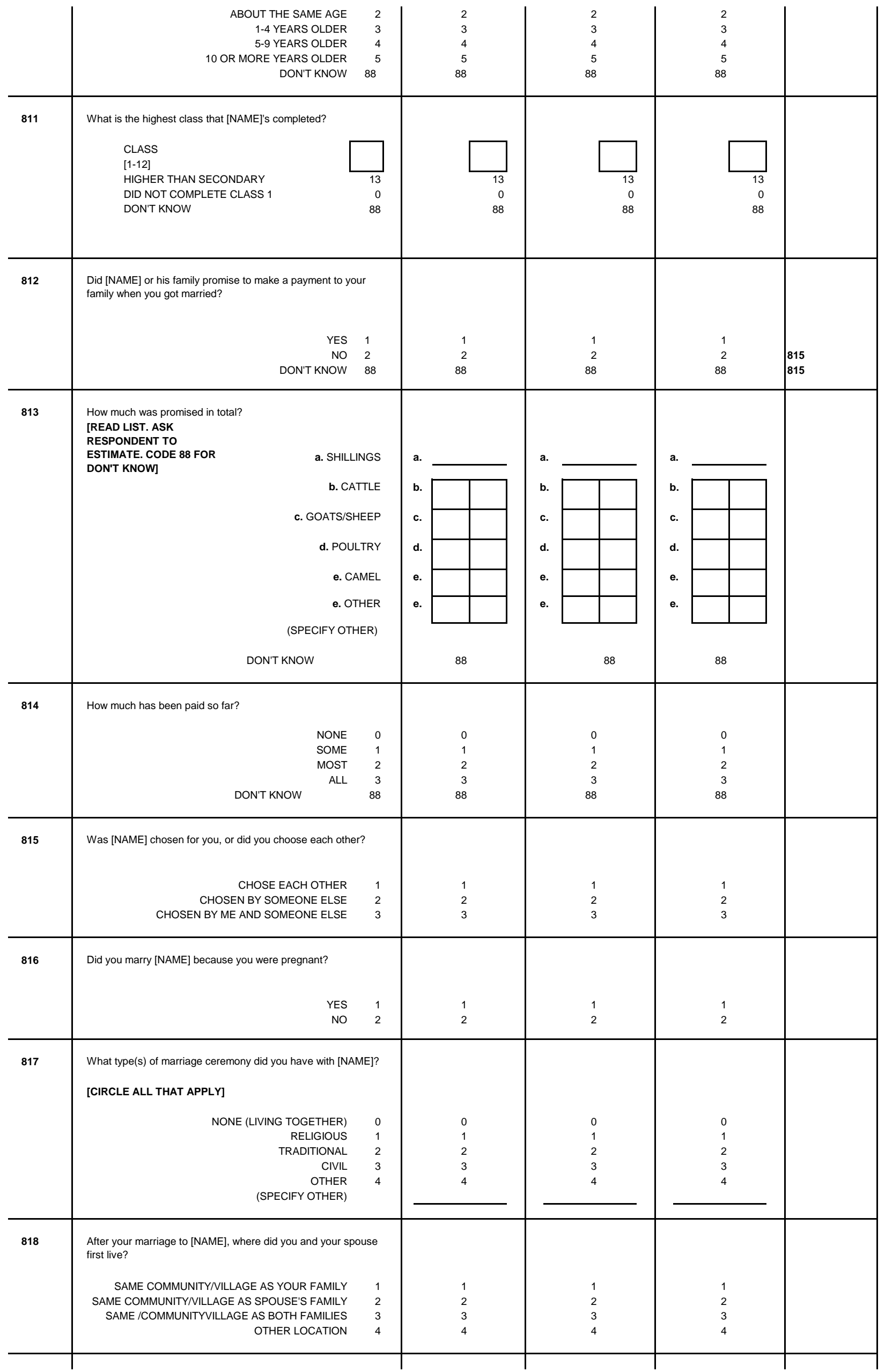




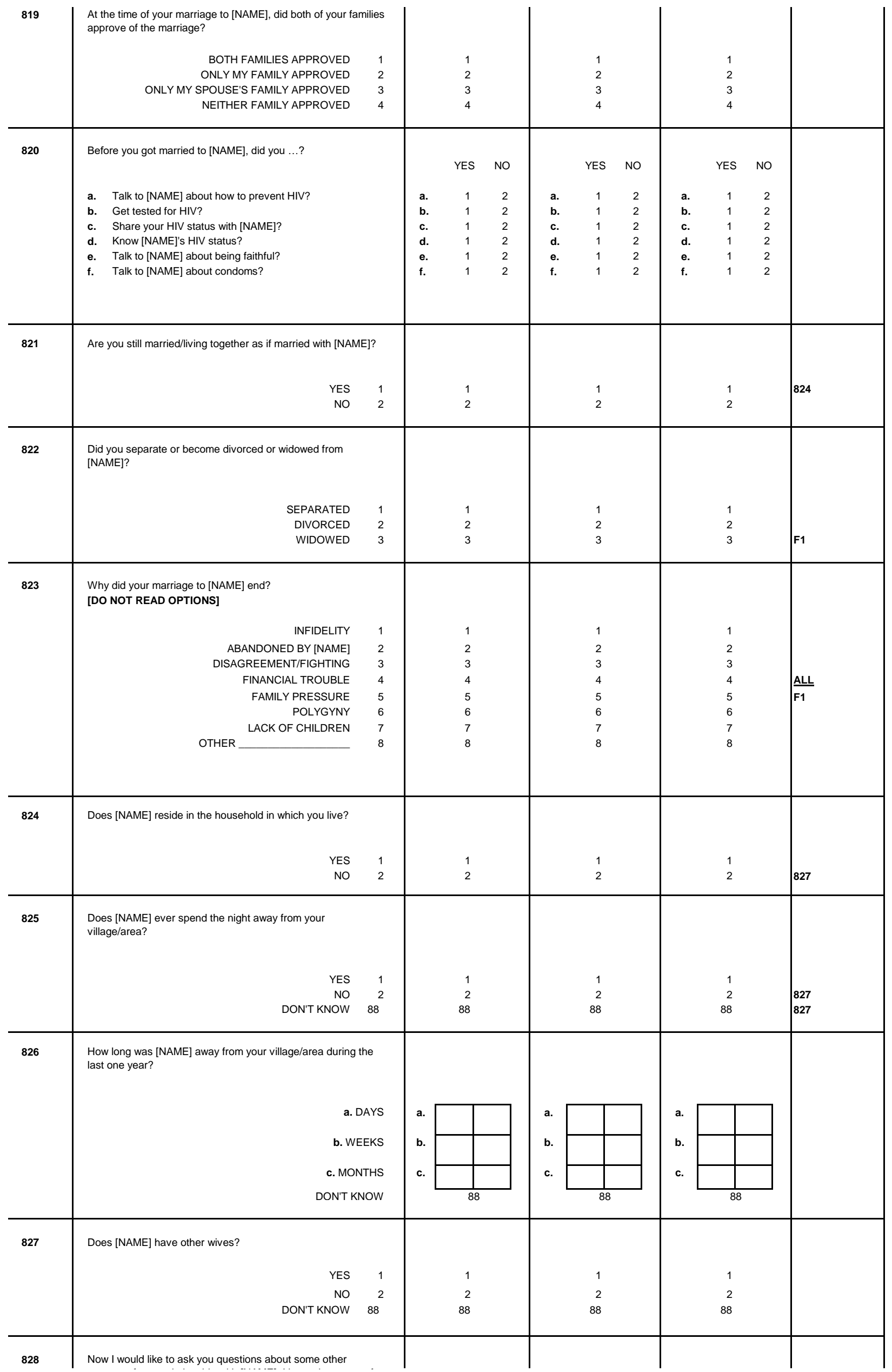


aspects of your relationship with [NAME] I know that some of these questions are very personal. Let me assure you that your answers are completely confidential and will not be told to anyone. I am going to read a series of statement about relationships between husbands and wives and I want you to tell me if it applies to your relationship with [NAME].

[NAME] is/was jealous or angry if you talk to other boys/men.

b [NAME] frequently accuses/accused you of being unfaithful.

c [NAME] permits/permitted you to meet your female friends.

d [NAME] tries/tried to limit contact with your family.

e. [NAME] insists/insisted on knowing where you are at all times.

f. [NAME] trusts/trusted you with money

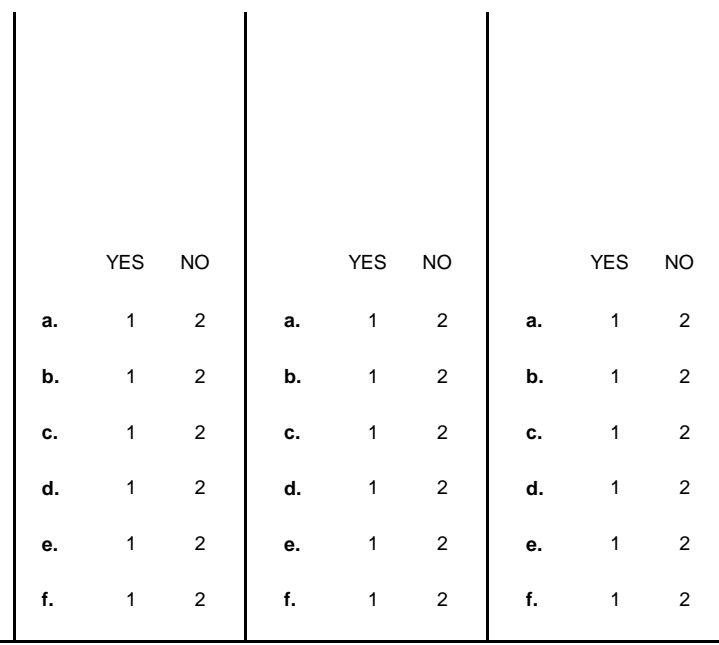

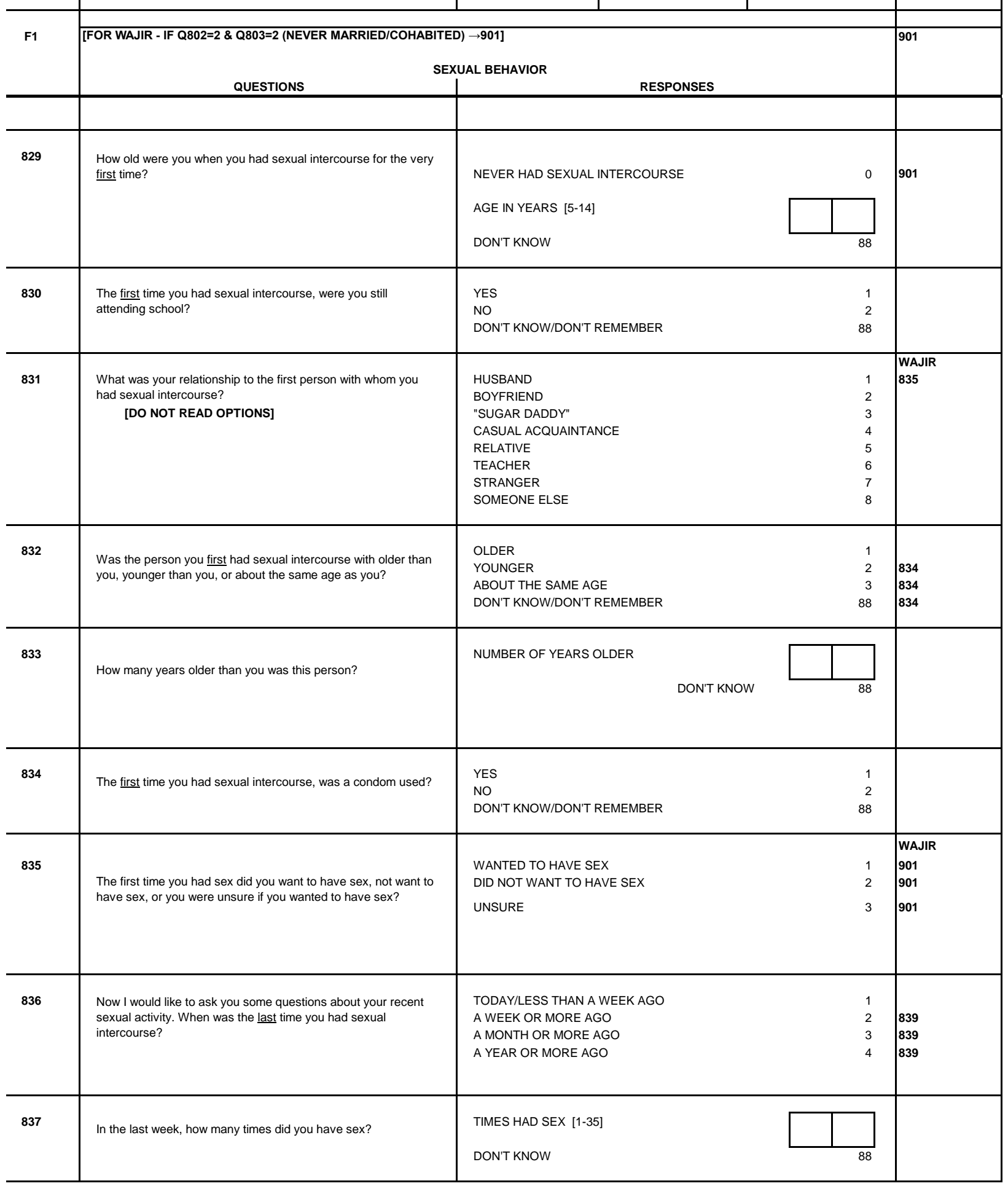




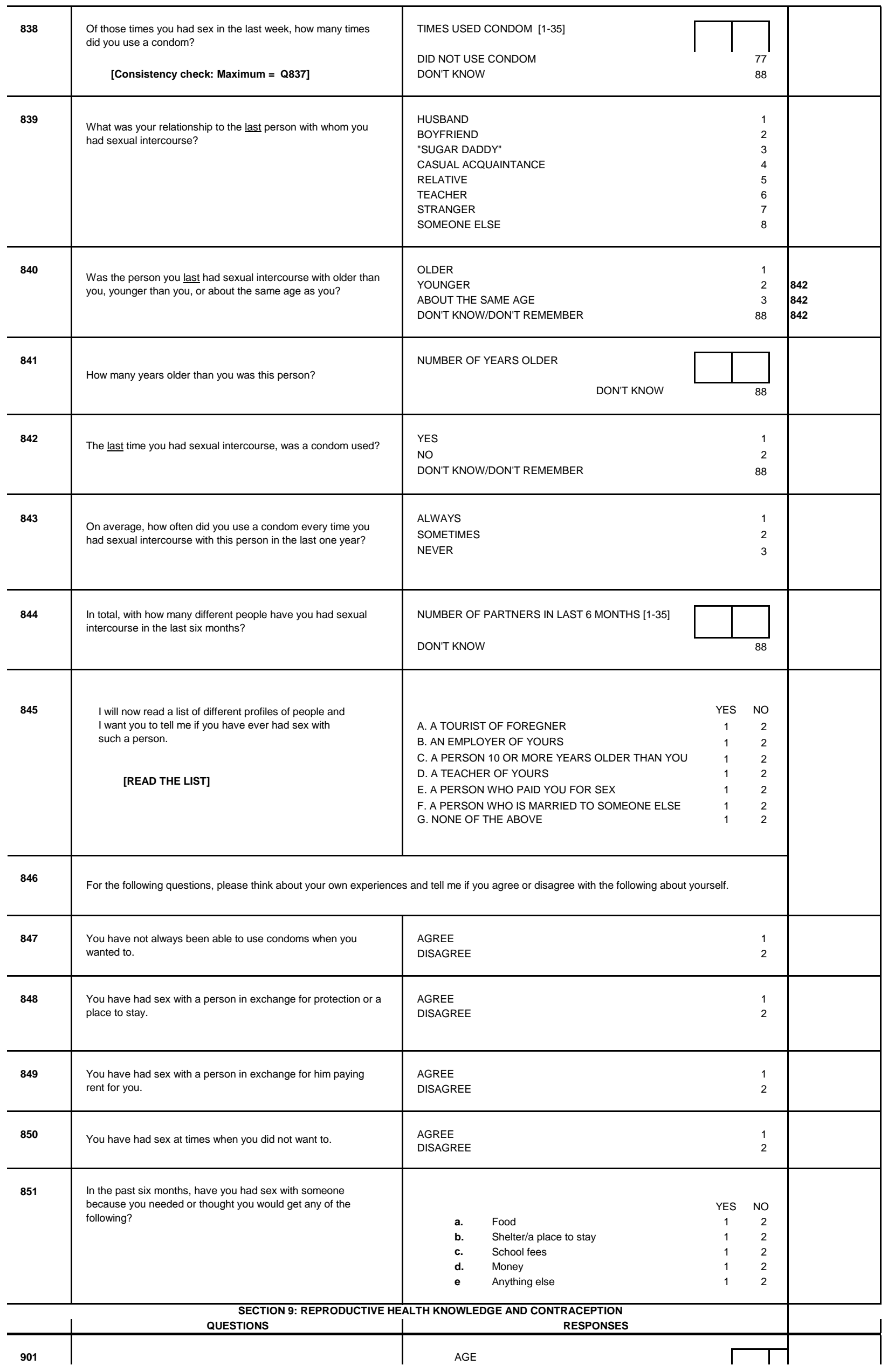


[4-15]

DON'T KNOW

HAS NOT BEGUN MENSTRUATING

\begin{tabular}{c|l|l} 
& At what age did you begin getting your menstrual period? & $\begin{array}{l}{[4-15]} \\
\text { DON'T KNOW } \\
\text { HAS NOT BEGUN MENSTRUATING }\end{array}$ \\
\hline 902 & $\begin{array}{l}\text { From one menstrual period to the next, are there certain days } \\
\text { when a woman is more likely to become pregnant if she has } \\
\text { sexual relations? }\end{array}$ & $\begin{array}{l}\text { YES } \\
\text { NO } \\
\text { DON'T KNOW }\end{array}$ \\
\hline \multirow{903}{*03}{} & $\begin{array}{ll}\text { Is this time just before her period begins, during her period, } \\
\text { right after her period has ended, or two weeks after her period? }\end{array}$ & $\begin{array}{l}\text { JUST BEFORE HER PERIOD BEGINS } \\
\text { DURG HER PERIOD }\end{array}$ \\
& $\begin{array}{l}\text { RIGHT AFTER HER PERIOD ENDS } \\
\text { HALFWAY BETWEEN TWO PERIODS } \\
\text { OTHER } \\
\text { DON'T KNOW }\end{array}$ \\
\hline
\end{tabular}

Now I would like to talk about family planning - the various ways or methods that a couple can use to delay or avoid a pregnancy.

Which ways or methods have you heard about?

[FOR METHODS NOT MENTIONED SPONTANEOUSLY, ASK:

Have you heard of (METHOD)?]

[IF Q802=2 \& Q803=2 \& Q829=0] $\rightarrow$

F2

Have you ever use [METHOD]?

2904

$88 \quad 904$

1

3

4

6

$=0] \rightarrow$

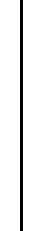

a. PILL: Women can take a pill every day to avoid becoming pregnant.

YES, SPONT

YES, RECOG

NO

b. IUD: Women can have a loop or coil placed inside them by a doctor or a nurse.

YES, SPONT

YES, RECOG

NO

c. INJECTABLES: Women can have an injection by a health
provider that stops them from becoming pregnant for one
or more months.

IMPLANTS: Women can have several small rods placed in their upper arm by a doctor or nurse which can prevent pregnancy for one or more years.

YES, SPONT

YES, RECOG

NO

YES

NO

\begin{tabular}{r|r|}
\hline & \\
88 & \\
77 & \\
& \\
1 & \\
2 & 904 \\
88 & 904
\end{tabular}

e. MALE CONDOM: Men can put a rubber sheath on their MALE CONDOM: Men can put a rubber
erect penis before sexual intercourse.

on their

YES, SPONT

YES, RECOG

NO

YES, SPONT

NO rect penis betore sexual intercourse.

f. FEMALE CONDOM: Women can place a thin, transparent rubber in their vagina before sexual intercourse.

transparent

g.

RHYTHM METHOD: Every month that a woman is sexually active she can avoid pregnancy by not having sexual intercourse on the days of the month she is most likely to get pregnant.

.

h. WITHDRAWAL: Men can pull out their penis from the vagina before ejaculation.

YES, SPONT

YES, RECOG NO

\begin{tabular}{l|l|l|} 
& h. WITHDRAWAL: Men can pull out their penis from the \\
vagina before ejaculation.
\end{tabular}

EMERGENCY CONTRACEPTION: As an emergency measure, women can take pills up to three days after having unprotected sex to avoid getting pregnant. These pills are also called "morning-after pills".

\begin{tabular}{l|ll}
1 & YES & 1 \\
2 & NO & 2 \\
3 &
\end{tabular}

YES, SPONT

YES, RECOG

NES,

\begin{tabular}{l|l|l|l|} 
& $\begin{array}{l}\text { Neasure, women can take pills up to three days after } \\
\text { having unprotected sex to avoid getting pregnant. These } \\
\text { pills are also called "morning-after pills". }\end{array}$ & NO & \\
\hline F2 & [IF Q802=2 \& Q803=2 \& Q829=0 (NEVER MARRIED/COHABITED \& NEVER HAD SEX) $\rightarrow$ Q1101] & $\mathbf{1 1 0 1}$ \\
\hline
\end{tabular}

\begin{tabular}{ll|l}
1 & \\
2 & & \\
3 & &
\end{tabular}

(2)




\begin{tabular}{|c|c|c|c|c|c|c|}
\hline & \multicolumn{5}{|c|}{ SECTION 10: PREGNANCY AND BIRTHS } & \\
\hline & QUESTIONS & \multicolumn{4}{|c|}{ RESPONSES } & \\
\hline 1001 & $\begin{array}{l}\text { Now I would like to ask you about all the births you have had } \\
\text { during your life. Have you ever given birth? }\end{array}$ & $\begin{array}{l}\text { YES } \\
\text { NO }\end{array}$ & & & $\begin{array}{l}1 \\
2\end{array}$ & 1003 \\
\hline 1002 & $\begin{array}{l}\text { Have you ever given birth to a boy or girl who was born alive } \\
\text { but later died? }\end{array}$ & $\begin{array}{l}\text { YES } \\
\text { NO }\end{array}$ & & & $\begin{array}{l}1 \\
2\end{array}$ & 1004 \\
\hline 1003 & How many births have you had in total during your life? & $\begin{array}{l}\text { TOTAL BIRTHS } \\
{[1-5]}\end{array}$ & & & & \\
\hline 1004 & Are you pregnant now? & $\begin{array}{l}\text { YES } \\
\text { NO } \\
\text { UNSURE/DON'T KNO }\end{array}$ & & & $\begin{array}{r}1 \\
2 \\
88\end{array}$ & $\begin{array}{l}1007 \\
1007\end{array}$ \\
\hline 1005 & $\begin{array}{l}\text { How many months pregnant are you? } \\
\text { [RECORD NUMBER OF COMPLETED MONTHS] }\end{array}$ & $\begin{array}{l}\text { MONTHS } \\
{[0-10]} \\
\text { DON'T KNOW }\end{array}$ & & & 88 & \\
\hline 1006 & $\begin{array}{l}\text { At the time you became pregnant, did you want to become } \\
\text { pregnant then, did you want to wait until later, or did you not } \\
\text { want the pregnancy at all? }\end{array}$ & $\begin{array}{l}\text { THEN } \\
\text { LATER } \\
\text { NOT AT ALL }\end{array}$ & & & $\begin{array}{l}1 \\
2 \\
3\end{array}$ & F3 \\
\hline 1007 & $\begin{array}{l}\text { Sometimes a girl becomes pregnant when she does not want to } \\
\text { be. Have you ever been pregnant when you did not want to be? }\end{array}$ & $\begin{array}{l}\text { YES } \\
\text { NO }\end{array}$ & & & $\begin{array}{l}1 \\
2\end{array}$ & \\
\hline F3 & [IF ALL OF $1001,1002,1004$, AND $1007=$ NO $\rightarrow 1015]$ & & & & & \\
\hline 1008 & $\begin{array}{l}\text { Have you ever had a pregnancy that miscarried, or ended in a } \\
\text { stillbirth? }\end{array}$ & $\begin{array}{l}\text { YES } \\
\text { NO }\end{array}$ & & & $\begin{array}{l}1 \\
2\end{array}$ & \\
\hline 1009 & $\begin{array}{l}\text { When you found out you were pregnant for the very first time, } \\
\text { were you still attending school? }\end{array}$ & $\begin{array}{l}\text { YES } \\
\text { NO }\end{array}$ & & & $\begin{array}{l}1 \\
2\end{array}$ & \\
\hline 1010 & $\begin{array}{l}\text { When you found out you were pregnant for the very first time, } \\
\text { were you single, engaged or married? }\end{array}$ & $\begin{array}{l}\text { SINGLE } \\
\text { ENGAGED } \\
\text { MARRIED }\end{array}$ & & & $\begin{array}{l}1 \\
2 \\
3\end{array}$ & \\
\hline F4 & $\begin{array}{l}\text { [IF } 1004=1 \rightarrow \text { ASK CURRENT PREGNANCY FOR Q1011-101 } \\
\text { [IF } 1001=1 \text { OR } 1002=1 \text { OR } 1007=1 \rightarrow \text { ASK LAST PREGNA }\end{array}$ & FOR Q1011-1014] & & & & \\
\hline & & CURRENT PREG & & LAST PREGNAN & & \\
\hline 1011 & $\begin{array}{l}\text { Now I would like to ask some questions about your } \\
\text { [CURRENT/LAST] pregnancy. } \\
\text { Have you seen/did you see anyone for antenatal care for this } \\
\text { pregnancy? } \\
\text { IF YES: } \\
\text { Whom did you see? } \\
\text { Probe: Anyone else? } \\
\text { [RECORD ALL MENTIONED, IF NONE, RECORD 'NO ONE'] }\end{array}$ & $\begin{array}{l}\text { DOCTOR } \\
\text { CLINICAL OFFICER } \\
\text { NURSE/MIDWIFE } \\
\text { TRADITIONAL BIRTH } \\
\quad \text { ATTENDANT } \\
\text { OTHER } \\
\text { NO ONE }\end{array}$ & $\begin{array}{l}11 \\
12 \\
13 \\
21 \\
96 \\
97\end{array}$ & $\begin{array}{l}\text { DOCTOR } \\
\text { CLINICAL OFFICER } \\
\text { NURSE/MIDWIFE } \\
\text { TRADITIONAL BIRTH } \\
\quad \text { ATTENDANT } \\
\text { OTHER } \\
\text { NO ONE }\end{array}$ & $\begin{array}{l}11 \\
12 \\
13 \\
21 \\
96 \\
97\end{array}$ & 1016 \\
\hline 1012 & $\begin{array}{l}\text { Where did you receive antenatal care for this pregnancy? } \\
\text { Probe: Anywhere else? } \\
\text { [RECORD ALL MENTIONED] }\end{array}$ & $\begin{array}{l}\text { YOUR HOME } \\
\text { OTHER HOME } \\
\text { GOVT. HOSPITAL } \\
\text { GOVT. HEALTH } \\
\text { CENTER } \\
\text { GOVT. HEALTH } \\
\quad \text { POST } \\
\text { OTHER PUBLIC } \\
\text { PVT. HOSPITAL/ } \\
\text { CLINIC } \\
\text { MISSION HOSPITAL/ } \\
\text { CLINIC } \\
\text { OTHER PRIVATE }\end{array}$ & $\begin{array}{l}11 \\
12 \\
21 \\
\\
22 \\
\\
23 \\
26 \\
31 \\
\\
32 \\
36\end{array}$ & $\begin{array}{l}\text { YOUR HOME } \\
\text { OTHER HOME } \\
\text { GOVT. HOSPITAL } \\
\text { GOVT. HEALTH } \\
\text { CENTER } \\
\text { GOVT. HEALTH } \\
\text { POST } \\
\text { OTHER PUBLIC } \\
\text { PVT. HOSPITAL/ } \\
\text { CLINIC } \\
\text { MISSION HOSPITAL/ } \\
\text { CLINIC } \\
\text { OTHER PRIVATE }\end{array}$ & $\begin{array}{l}11 \\
12 \\
21 \\
\\
22 \\
\\
23 \\
26 \\
\\
31 \\
\\
32 \\
36\end{array}$ & $\begin{array}{l}1014 \\
1014\end{array}$ \\
\hline
\end{tabular}




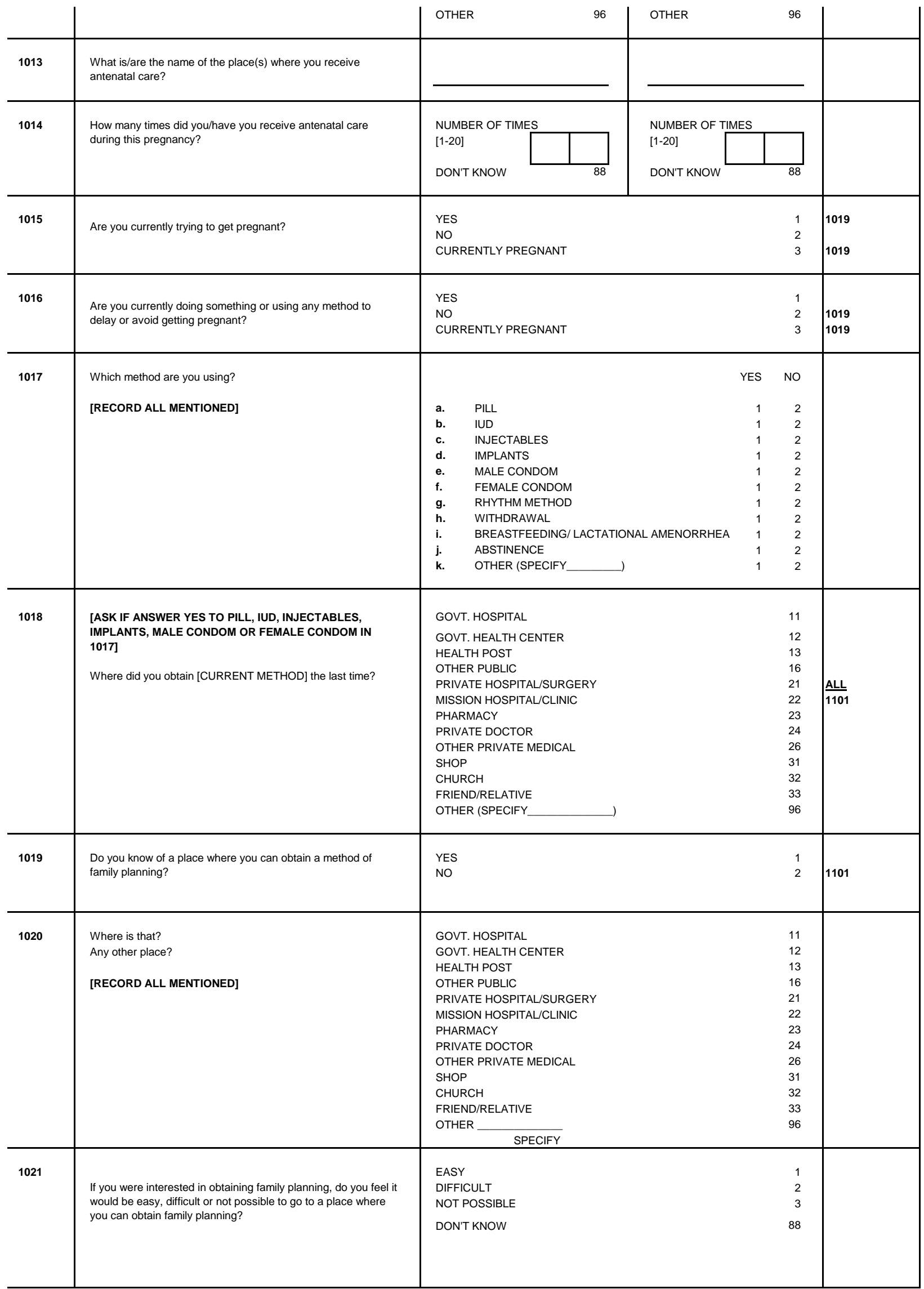

\begin{tabular}{l|l|l|l|}
\multicolumn{2}{|c|}{ SECTION 11: NUTRITION } & RESPONSES \\
\hline \multirow{3}{*1101}{} & & & \\
\hline & \multirow{2}{*}{$\begin{array}{l}\text { Now I would like to ask you about (other) liquids or foods that } \\
\text { you may have had yesterday during the day or at night. I am } \\
\text { interested in whether vou had the item even if it was combined }\end{array}$} & & \\
\cline { 3 - 4 } & &
\end{tabular}


RESONSE

with other foods. Did you drink (eat): sorguhm or other local grains

b. Pumpkin, yellow yams, butternut, carrots or yellow sweet potatoes

c. Any other food made from roots or tubers, like white potatoes, arrowroot, cassava or other roots or tubers?

ROOTS, TUBERS.

d. Any green leafy vegetables?

e. Mango, pawpaw, guava?

f. Any other fruits and vegetables like bananas, apples, green beans, avocados, tomatoes, oranges, pineapples,passion frut

g. Meat, chicken, fish, liver, kidney, blood, termites, sea food or eggs?

h. Any food made from legumes, e.g. lentils, beans, soybeans, pulse or pea nuts?

i. Sour milk, cheese, or yoghurt?

j. Any oil, fats, blue band or butter, or foods made with any of these?

Any sugary foods such as chocolates, sweets, candies, pastries, cakes, or biscuits?

Any other solid or semi-solid food?

Do you have the following items in your household?

a. Salt

b. Sugar

b. SUGAR

ANY OTHER SOLID OR MUSHY FOOD

SOUR MILK, CHEESE

j. OILS, FATS

k. SUGARY FOODS

1288

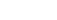

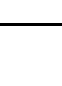

YES NO DK

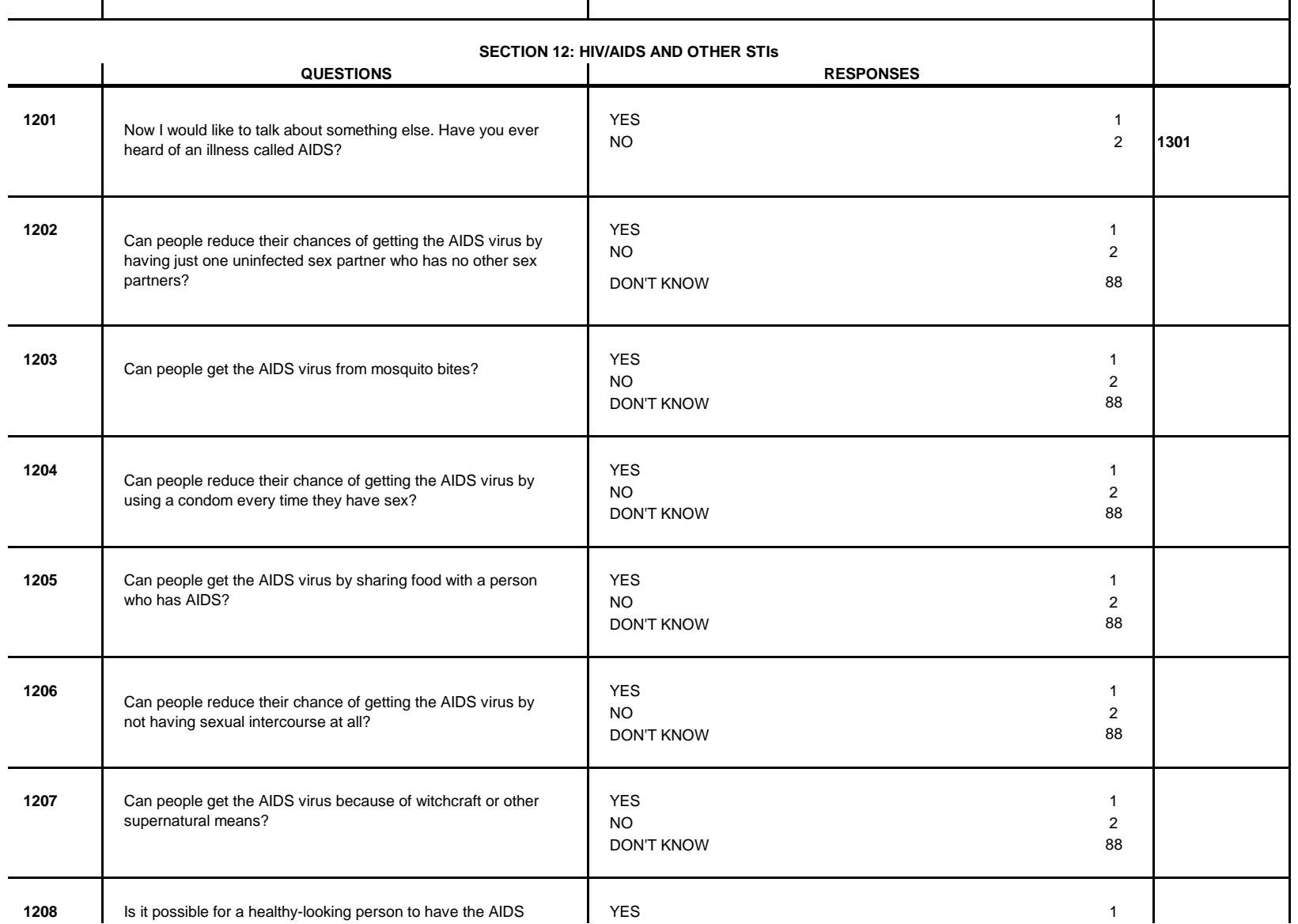




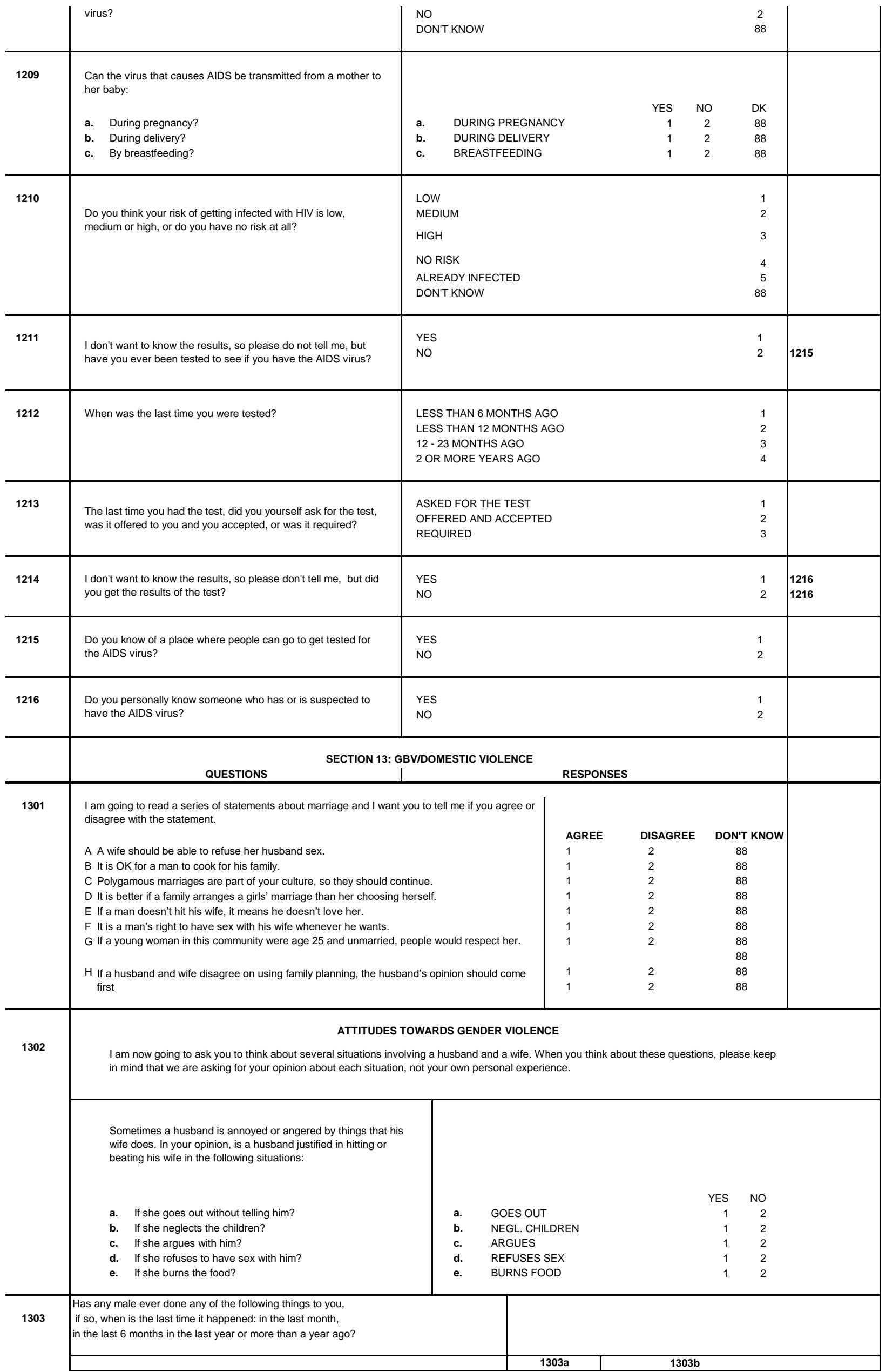


A. Say or do something to humiliate you in front of others?

B. Threaten to hurt or harm you or someone close to you?

C. Insult you or make you feel bad about yourself?

D. Push you, shake you, or throw something at you

E. Slap you

F. Twist your arm or pull your hair

G. Punch you with his fist or something that could hurt you

H. Kick you, drag you, or beat you up

I. Try to choke you or burn you on purpose

J. Threatened to attack you with a knife or other weapon

K. Attacked you with a weapon
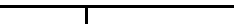
did not want them to

M. Try to have sexual intercourse with you when you did not want to but did not succeed

N. Physically forced you to have sexual intercourse even when you did not want to

O. Forced you to perform sexual acts when you did not want to

\begin{tabular}{|c|c|c|c|c|c|c|}
\hline \multicolumn{2}{|c|}{$\begin{array}{l}\text { Ever } \\
\text { Happen }\end{array}$} & \multicolumn{4}{|c|}{ WHEN HAPPENED } & \\
\hline YES & NO & $\begin{array}{c}\text { IN THE LAST } \\
\text { MONTH }\end{array}$ & \begin{tabular}{|l|} 
IN LAST 6 \\
MONTHS
\end{tabular} & $\begin{array}{l}\text { IN LAST } \\
\text { YEAR }\end{array}$ & \begin{tabular}{|l|} 
MORE THAN \\
1 YEAR AGO
\end{tabular} & \\
\hline 1 & 2 & 1 & 2 & 3 & 4 & \\
\hline 1 & 2 & 1 & 2 & 3 & 4 & \\
\hline 1 & 2 & 1 & 2 & 3 & 4 & \\
\hline 1 & 2 & 1 & 2 & 3 & 4 & \\
\hline 1 & 2 & 1 & 2 & 3 & 4 & \\
\hline 1 & 2 & 1 & 2 & 3 & 4 & \\
\hline 1 & 2 & 1 & 2 & 3 & 4 & \\
\hline 1 & 2 & 1 & 2 & 3 & 4 & \\
\hline 1 & 2 & 1 & 2 & 3 & 4 & \\
\hline 1 & 2 & 1 & 2 & 3 & 4 & \\
\hline 1 & 2 & 1 & 2 & 3 & 4 & \\
\hline 1 & 2 & 1 & 2 & 3 & 4 & \\
\hline 1 & 2 & 1 & 2 & 3 & 4 & \\
\hline 1 & 2 & 1 & 2 & 3 & 4 & \\
\hline 1 & 2 & 1 & 2 & 3 & 4 & \\
\hline$A D$ SE & ) & 310] & & & & 1310 \\
\hline & & YES & & & & \\
\hline ort fron & you & NO & & & 2 & \\
\hline & & DOES NC & PROVIDE & INANCIAL & SUPPORT & \\
\hline & & $\begin{array}{l}\text { NO HUSE } \\
\text { MONTHS }\end{array}$ & ND/PARTN & R IN THE & _AST SIX $\quad 88$ & 1310 \\
\hline sick & & $\begin{array}{l}\text { NUMBER } \\
{[1-200]}\end{array}$ & F TIMES & & & \\
\hline
\end{tabular}

1305

How many times in the last six months has your husband/partner hit, slapped, kicked or beaten you?

01308

\begin{tabular}{l|l|l} 
& & NON \\
\hline & &
\end{tabular}

\begin{tabular}{|c|c|c|c|c|c|}
\hline 1306 & \multicolumn{2}{|c|}{ The last time you were hit, slapped, kicked or beaten, do you think you deserved it? } & $\begin{array}{l}\text { YES } \\
\text { NO }\end{array}$ & $\begin{array}{l}1 \\
2\end{array}$ & \\
\hline 1307 & \multicolumn{2}{|c|}{$\begin{array}{l}\text { The last time you were hit, slapped, kicked or beaten, had your husband/partner been drinking or } \\
\text { using drugs? }\end{array}$} & $\begin{array}{l}\text { YES } \\
\text { NO }\end{array}$ & $\begin{array}{l}1 \\
2\end{array}$ & \\
\hline 1308 & Have you ever hit, slapped, kicked or beaten your husband & & $\begin{array}{l}\text { YES } \\
\text { NO }\end{array}$ & 1 & 1310 \\
\hline \multirow[t]{2}{*}{1309} & \multicolumn{2}{|c|}{$\begin{array}{l}\text { How many times in the last six months have you hit, slapped, kicked or beaten your } \\
\text { husband/partner? }\end{array}$} & $\begin{array}{l}\text { NUMBER OF TIMES } \\
{[1-200]} \\
\text { NONE }\end{array}$ & 0 & \\
\hline & QUESTIONS & & RESPONSES & & \\
\hline 1310 & $\begin{array}{l}\text { Thinking about what you have experienced among the } \\
\text { different things we have been talking about, have you } \\
\text { ever tried to seek help to stop them/the/those person(s) } \\
\text { from doing this to you again? }\end{array}$ & \multicolumn{2}{|c|}{ DID NOT EXPERIENCE OR N/A } & 2 & $\begin{array}{l}1313 \\
1313\end{array}$ \\
\hline
\end{tabular}


OWN FAMILY

HUSBAND/PARTNER'S FAMILY

CURRENT/LAST/LATE HUSBAND/ PARTNER

CURRENT/FORMER BOYFRIEND

FRIEND

NEIGHBOR

RELIGIOUS LEADER

DOCTOR/MEDICAL PERSONNEL

POLICE

LAWYER

SOCIAL SERVICE ORGANIZATION

COMMUNITYLEADER/LOCAL ADMN L

TEACHER

OTHER

\begin{tabular}{l|l|l} 
& & OTHEAC \\
\hline $\mathbf{1 3 1 2}$ & Have you ever told any one else about &
\end{tabular}

\begin{tabular}{l|l|ll}
1312 & $\begin{array}{l}\text { Have you ever told any one else about } \\
\text { this? }\end{array}$ & $\begin{array}{l}\text { YES } \\
\text { NO }\end{array}$ & $\begin{array}{c}1 \\
2\end{array}$ \\
\hline 1313 & $\begin{array}{l}\text { As far as you know, did your father/guardian ever beat your } \\
\text { mother/guardian? }\end{array}$ & $\begin{array}{l}\text { YES } \\
\text { NO } \\
\text { DON'T KNOW }\end{array}$ \\
\hline & \multicolumn{2}{|c}{ FEMALE CIRCUMCISION }
\end{tabular}

In some countries, there is a practice in which a girl may have part of her genitals cut.

Have you ever heard about this practice?

\begin{tabular}{l|l|l} 
& & \\
\hline $\mathbf{1 3 1 5}$ & Have you yourself ever been circumcised? & YES \\
& NO \\
\hline
\end{tabular}

IF THE RESPONDENT DOES NOT KNOW THE EXACT AGE, PROBE TO GET AN ESTIMATE.

\begin{tabular}{|c|c|c|c|}
\hline & PROBE TO GET AN ESTIMATE. & $\begin{array}{l}\text { DURING INFANCY } \\
\text { DON'T KNOW } \\
\end{array}$ & $\begin{array}{ll}9 & 5 \\
9 & 8 \\
\end{array}$ \\
\hline 1317 & $\begin{array}{l}\text { Do you intend to have [your daughter/any of your } \\
\text { daughters] circumcised? }\end{array}$ & \begin{tabular}{|l} 
YES \\
NO \\
DON'T KNOW \\
\end{tabular} & $\begin{array}{l}1 \\
2 \\
8 \\
\end{array}$ \\
\hline 1318 & $\begin{array}{l}\text { What benefits do girls themselves get if they are circumcised? } \\
\text { PROBE: Any other benefits? } \\
\text { [RECORD ALL MENTIONED.] }\end{array}$ & $\begin{array}{l}\text { CLEANLINESS/HYGIENE } \\
\text { SOCIAL ACCEPTANCE } \\
\text { BETTER MARRIAGE PROSPECTS } \\
\text { PRESERVE VIRGINITY/PREVENT } \\
\text { PREMARITAL SEX } \\
\text { MORE SEXUAL PLEASURE FOR THE MAN } \\
\text { RELIGIOUS APPROVAL } \\
\text { OTHER (SPECIFY) } \\
\text { NO BENEFITS }\end{array}$ & $\begin{array}{l}1 \\
2 \\
3 \\
4 \\
5 \\
\\
6 \\
7\end{array}$ \\
\hline 1319 & Do you think that this practice should be continued, or should it be stopped? & $\begin{array}{l}\text { CONTINUED } \\
\text { STOPPED } \\
\text { DEPENDS } \\
\text { DON'T KNOW }\end{array}$ & $\begin{array}{l}1 \\
2 \\
3 \\
4\end{array}$ \\
\hline
\end{tabular}

SECTION 14: CONCERNS, ASPIRATIONS, AND EXPECTATIONS OR PERCEIVED LIFE CHANCES

QUESTIONS AND FILTERS

Now, I would like to turn to some questions about some of

the worries and expectations you may have.

At this point in your life, how worried are you about (READ

STATEMENT). Are you very worried, somewhat

worried or not worried at all?

a. Your health?

b. Getting enough to eat?

c. Getting a good job?

d. Getting pregnant?

e. Getting HIV/AIDS?

f. Insecurity (e.g. rape, muggings, clan conflicts, "Mungiki")?

g. Harassment from police?

\begin{tabular}{|c|c|c|c|}
\hline $\begin{array}{l}\text { Very } \\
\text { worried }\end{array}$ & $\begin{array}{l}\text { Somewhat } \\
\text { worried }\end{array}$ & $\begin{array}{l}\text { Not } \\
\text { worried }\end{array}$ & $\begin{array}{l}\mathrm{N} / \mathrm{A} \text { or } \\
\text { Already } \\
\text { Have }\end{array}$ \\
\hline 1 & 2 & 3 & 8 \\
\hline 1 & 2 & 3 & 8 \\
\hline 1 & 2 & 3 & 8 \\
\hline 1 & 2 & 3 & 8 \\
\hline 1 & 2 & 3 & 8 \\
\hline 1 & 2 & 3 & 8 \\
\hline 1 & 2 & 3 & 8 \\
\hline
\end{tabular}




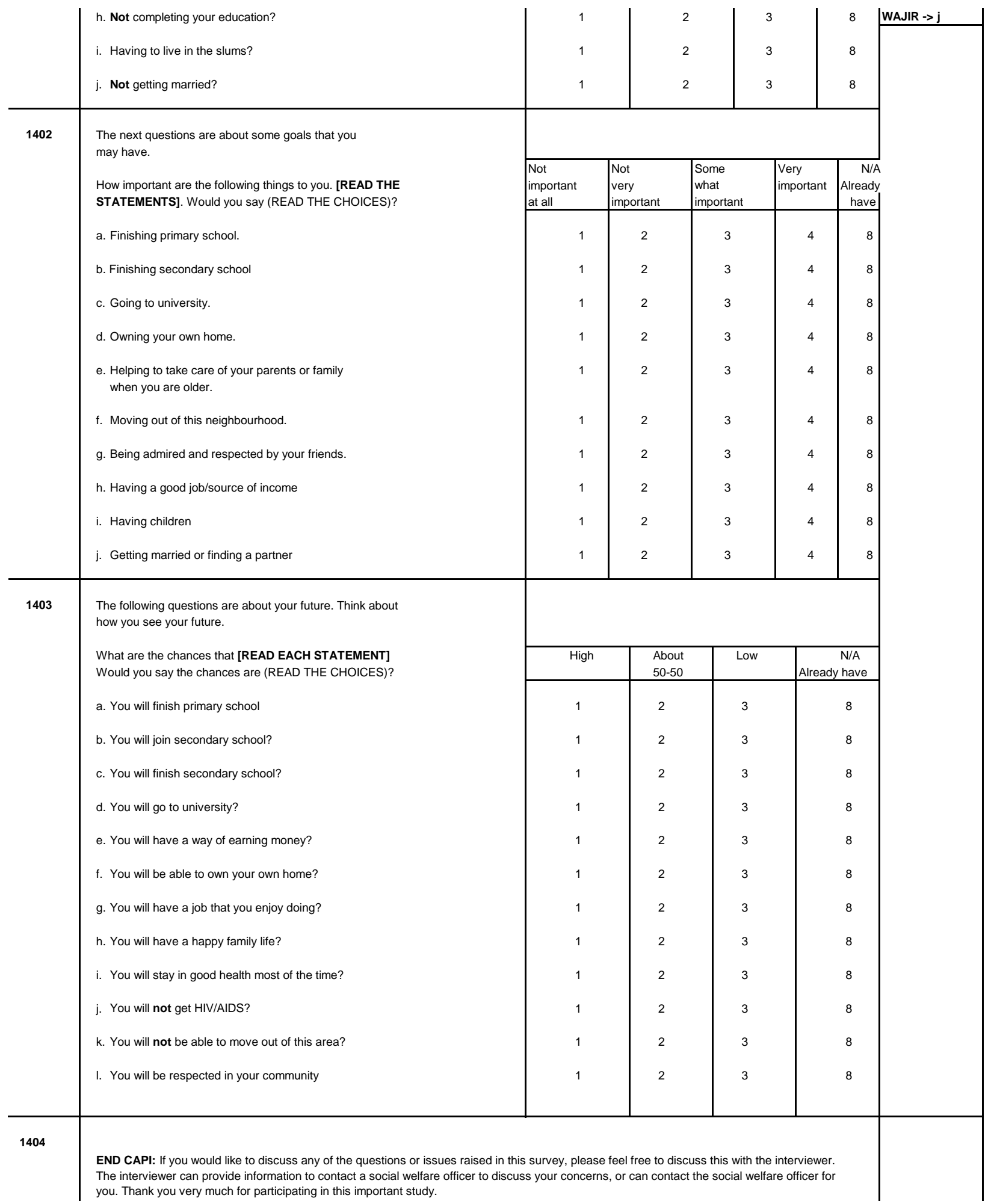




\section{ENGLISH}

Q330: RESPONDENT'S SCHOOLING HISTORY

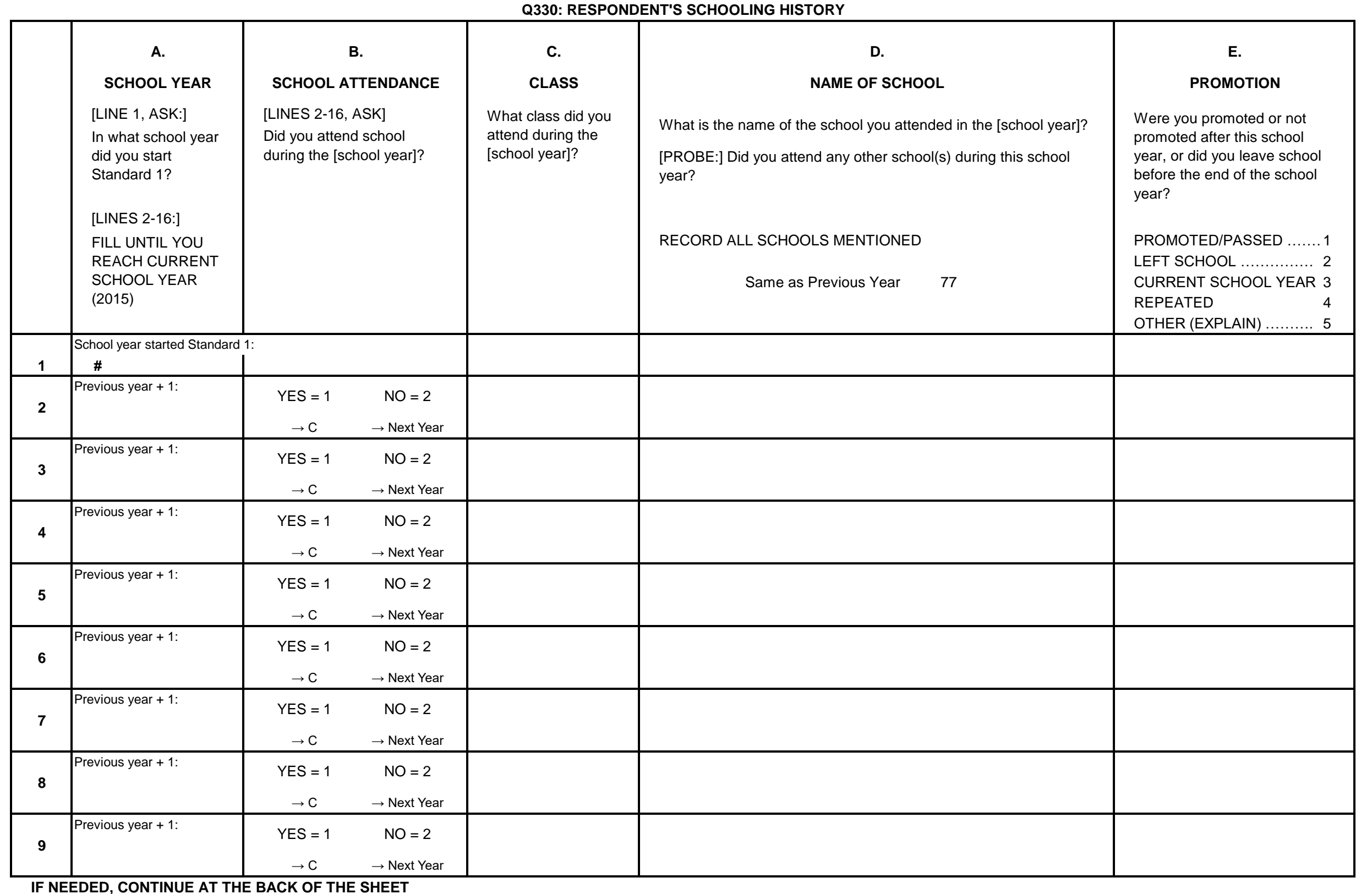

IF NEEDED, CONTINUE AT THE BACK OF THE SHEET 


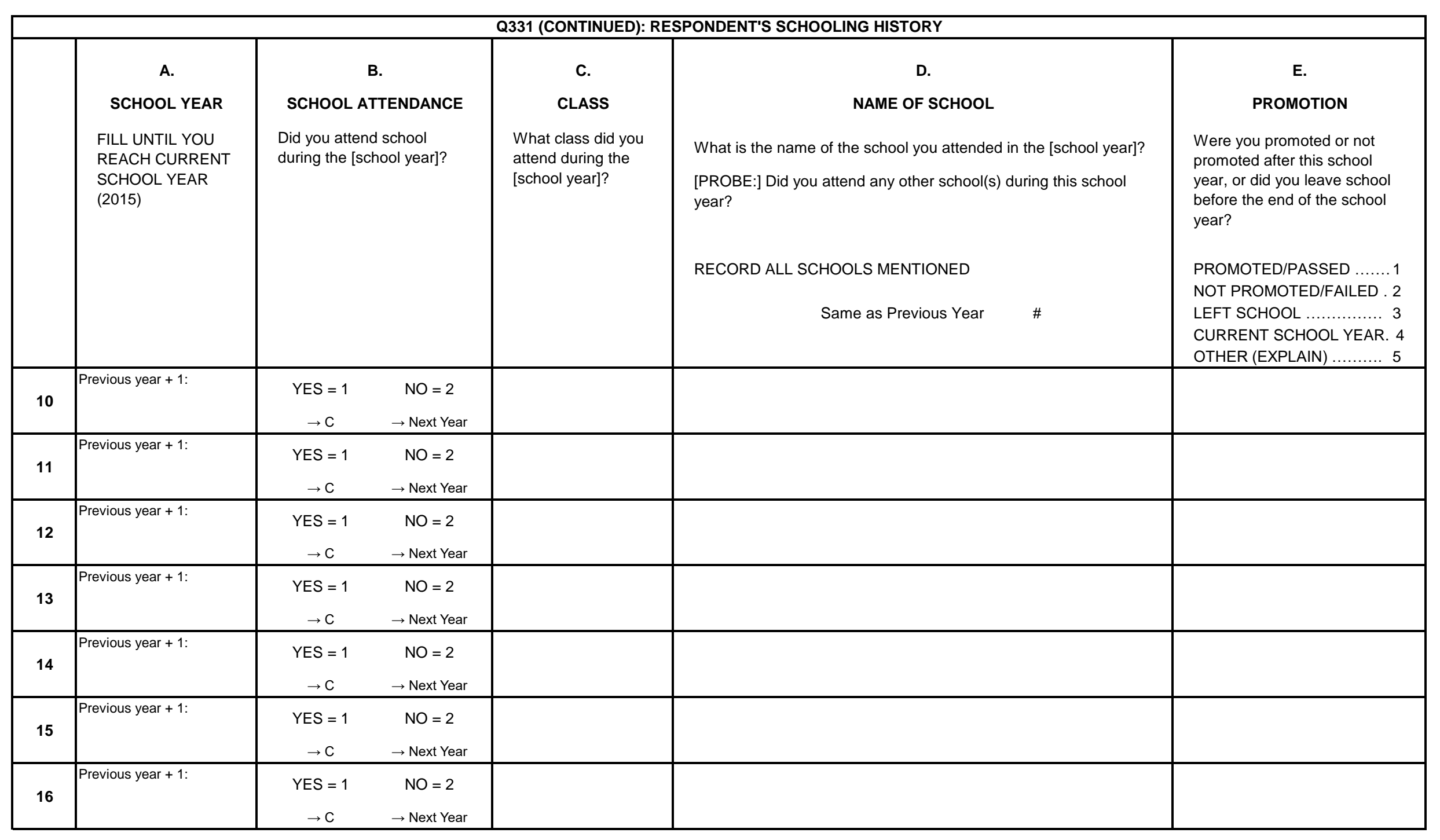




\section{ENGLISH}

Q406: RESPONDENT'S WORK IN LAST YEAR

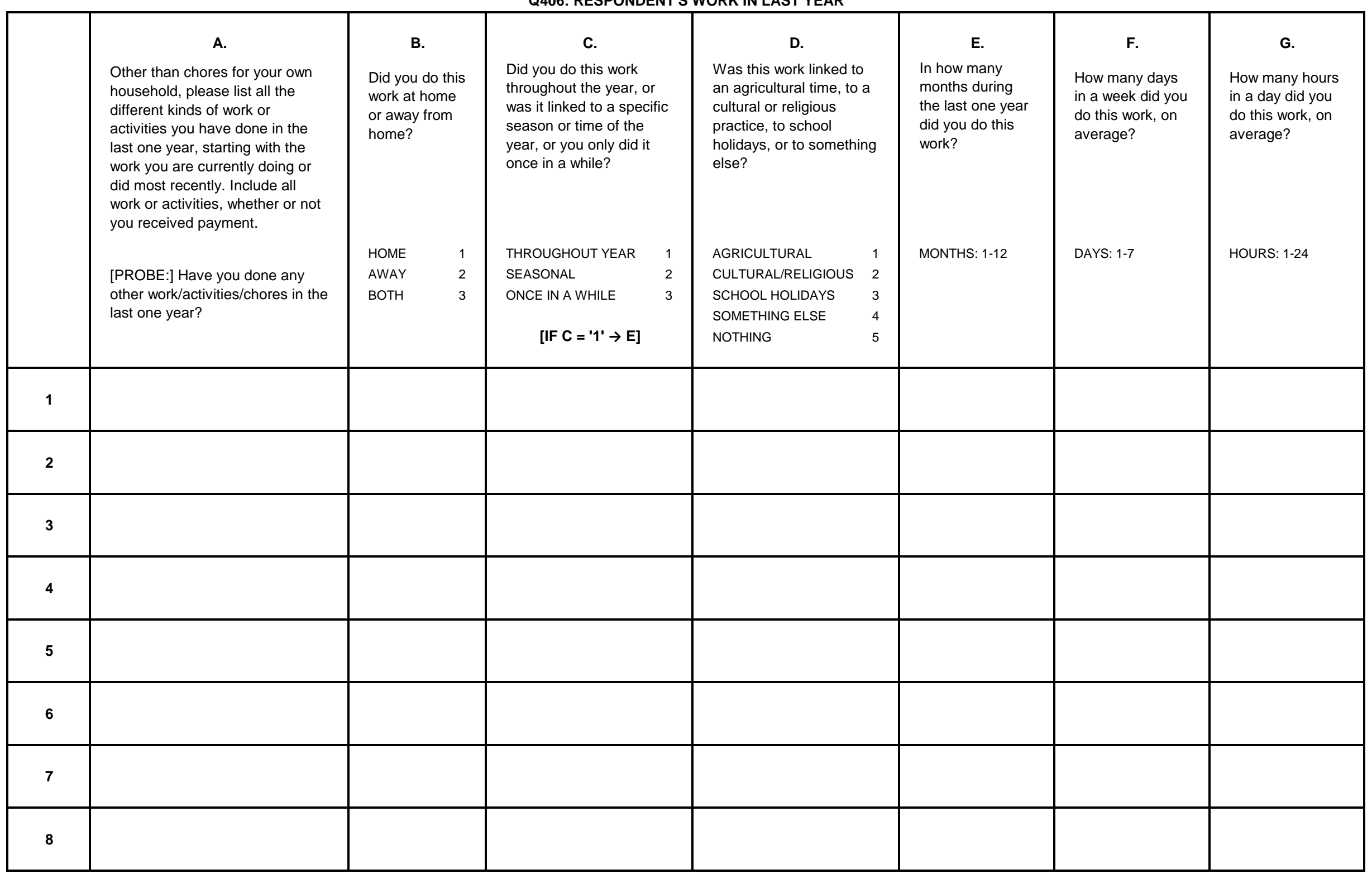

REMEMBER TO COMPLETE COLUMNS H, I, J, K, L AT THE BACK OF THE SHEET 


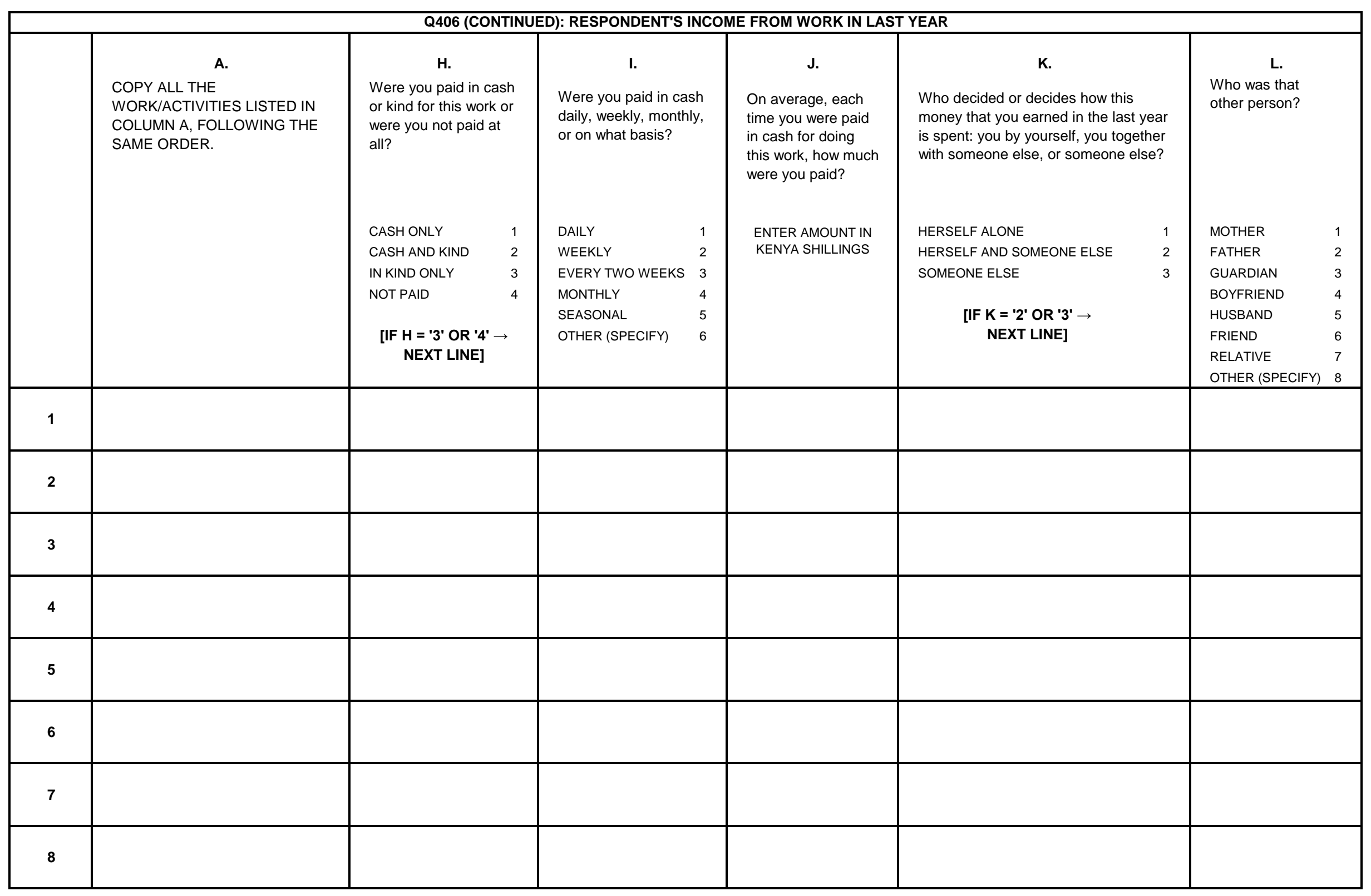




\section{ENGLISH}

Q411: RESPONDENT'S SPENDING IN PAST MONTH

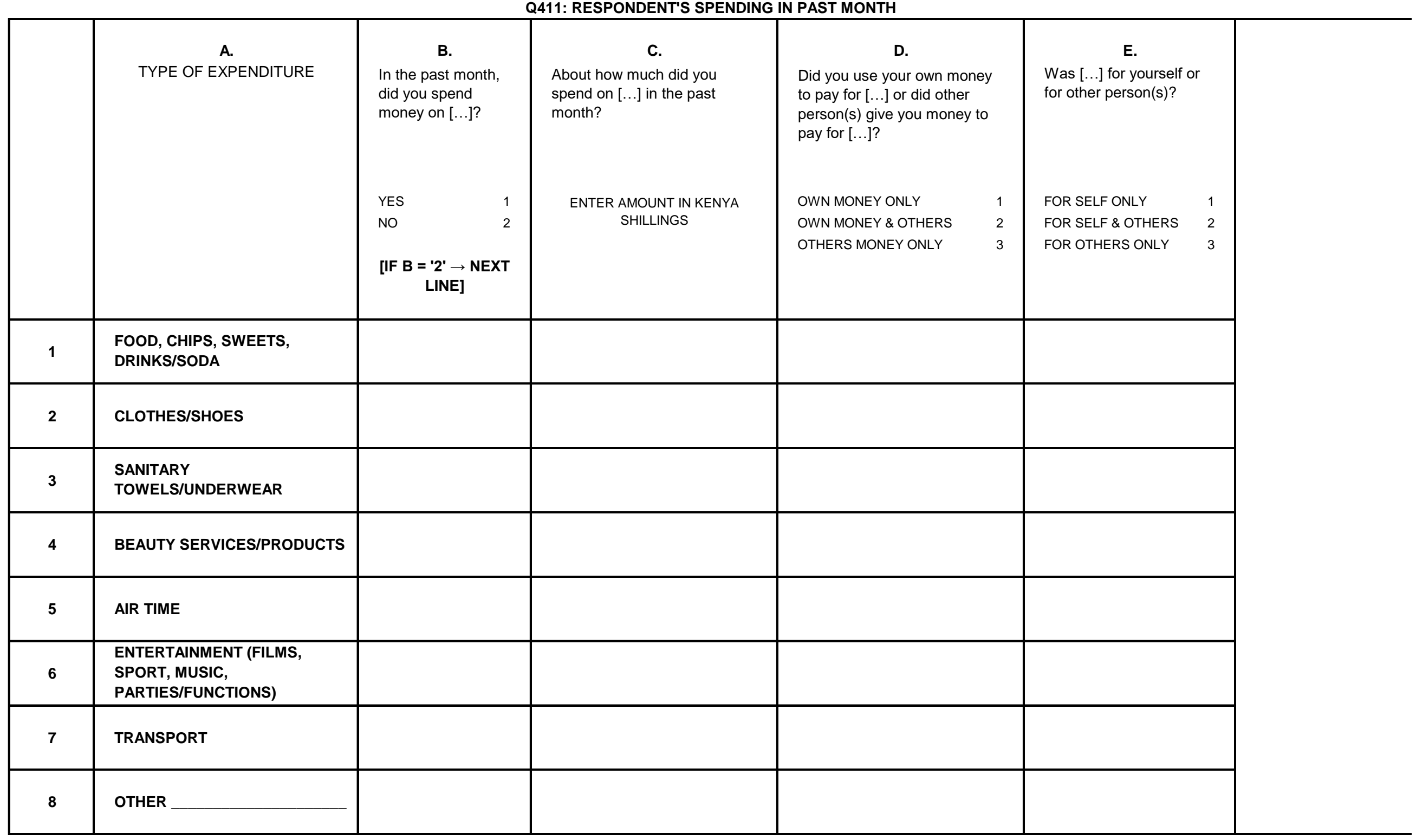

REMEMBER TO COMPLETE

COLUMNS G, H, I, J, K, L

AT THE BACK OF THE SHEET 


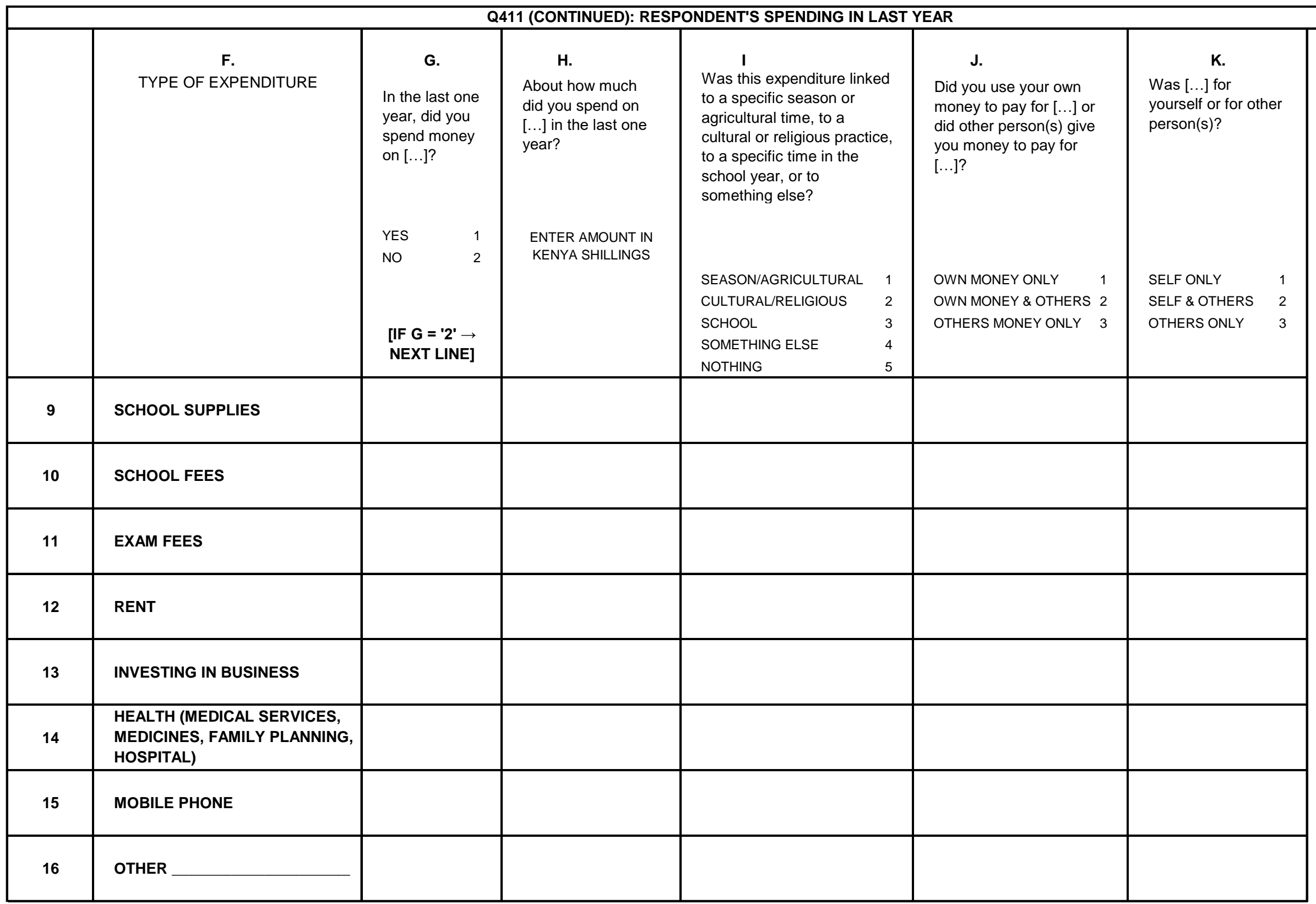




\section{KISWAHILI}

Q417: RESPONDENT'S SAVINGS IN LAST YEAR

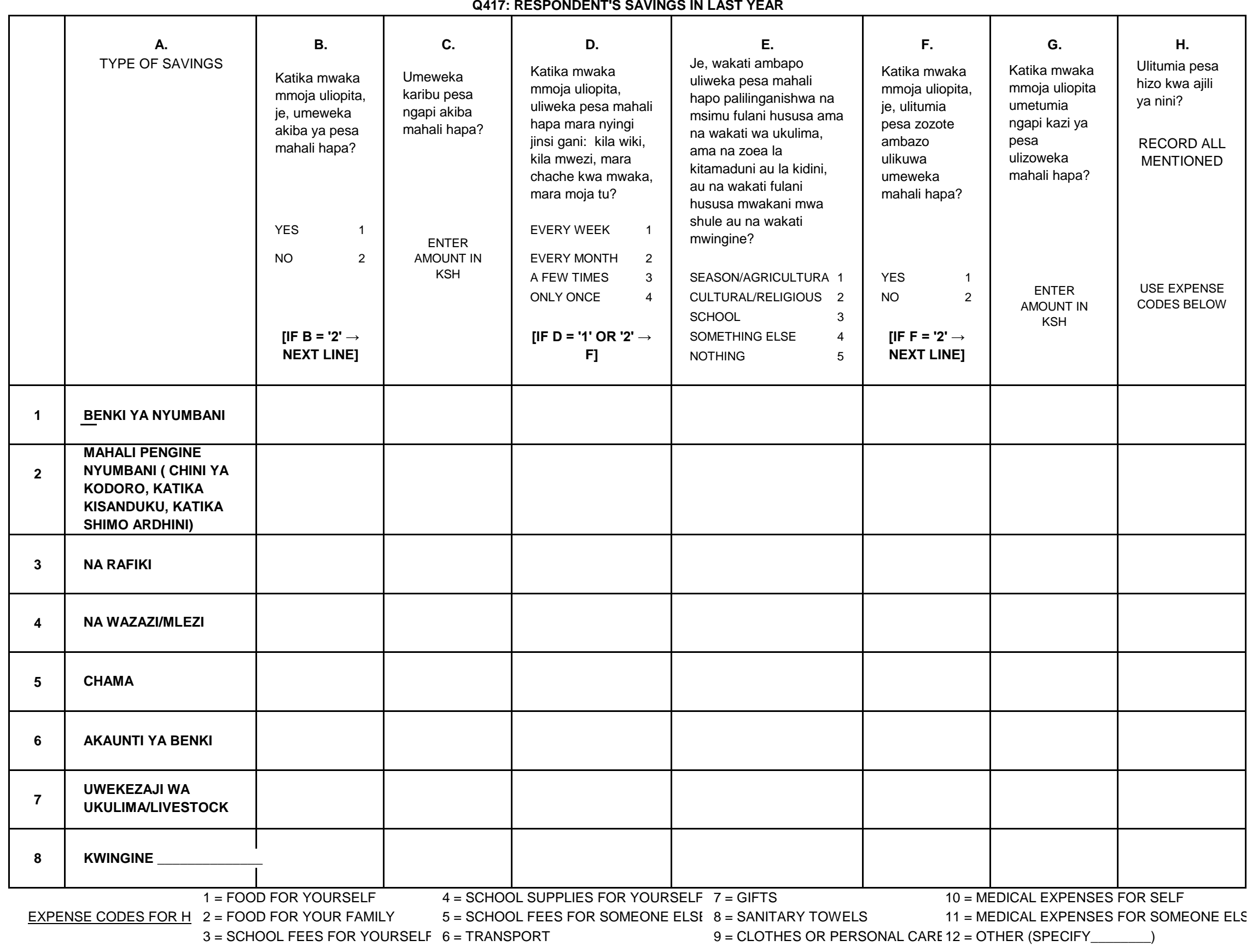




\section{ENGLISH}

Q417: RESPONDENT'S SAVINGS IN LAST YEAR

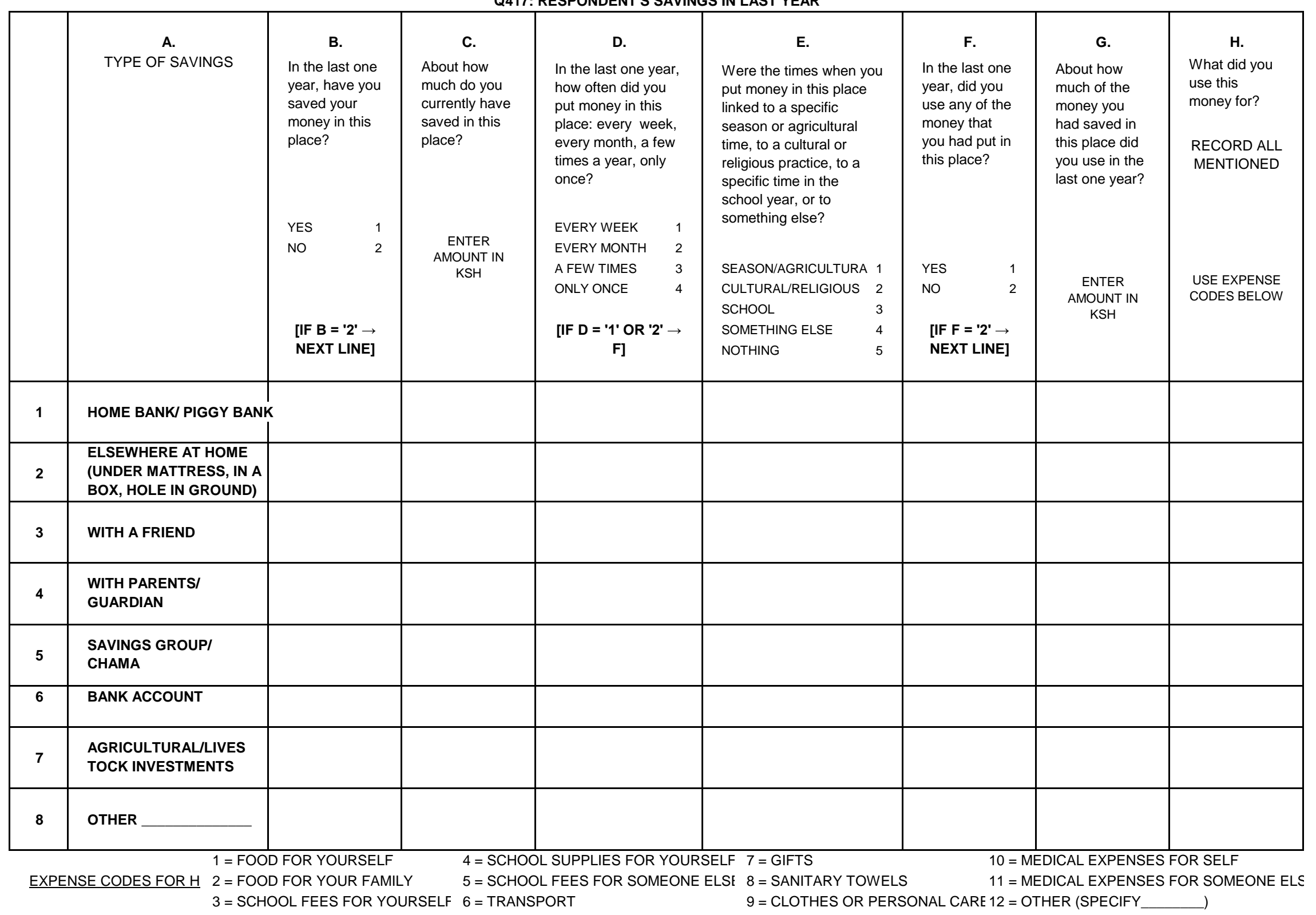

